PNL-3309

UC-95d

\title{
Analysis of Alternative Strategies for Energy Conservation in New Buildings
}

December 1980

Prepared for the Office of Conservation and Solar Energy Department of Energy

Contract No. DE-AC06-76RLO 1830

Pacific Northwest Laboratory

Operated for the U.S. Department of Energy

by Battelle Memorial Institute 


\title{
NOTICE
}

This report was prepared as an account of work sponsored by the United States Government. Neither the United States nor the Department of Energy, nor any of their employees, nor any of their contractors, subcontractors. or their employees, makes any warranty, express or implied, or assumes anv legal liability or responsibility for the accuracy, completeness or usefuiness of any information, apparatus, product or process disclosed, or represents that its use would not iniringe privately owned rights.

The views, opinions and conclusions contained in this report are those of the contractor and do not necessarily represent those of the United States Covernment or the United States Department of Energy.

\author{
PACIFIC NORTHWEST LABORATORY \\ operated by \\ BATTELLE \\ for the \\ UNITED STATES DEPARTMENT OF ENERCY \\ Under Contract DE-AC06-76RLO 1830
}

\author{
Printed in the Unired States of America \\ Available from \\ National Technical Information Service \\ United States Department of Commerce \\ 5285 Port Royal Road \\ Springfield. Virginia 22151
}

Price: Printed Copy $\$$

$\because$ Microfiche $\$ 3.00$

NTIS

- Pages Selling Price

$\begin{array}{ll}001-025 & \$ 4.00 \\ 026-050 & \$ 4.30 \\ 051-075 & \$ 5.25 \\ 076-100 & \$ 6.00 \\ 107-125 & \$ 6.50 \\ 126-150 & \$ 7.25 \\ 157-175 & \$ 8.00 \\ 176-200 & \$ 9.00 \\ 201-225 & \$ 9.25 \\ 226-250 & \$ 9.30 \\ 257-275 & \$ 10.75 \\ 276-300 & \$ 17.00\end{array}$

$276.300 \quad 371.00$ 
PNL-3309

UC-95d

\section{5}

ANALYSIS OF ALTERNATIVE STRATEGIES FOR ENERGY CONSERVATION IN NEW BUILDINGS

Jeffrey M. Fang

Jack J. Tawil

December 1980

Prepared for the Office of Conservation and Solar Energy, Department of Energy under Contract No. DE-ACO6-76RLO 1830

Pac ific Northwest Laboratory

Richland, Washington 99352 



\section{EXECUTIVE SUMMARY}

Building Energy Performance Standards (BEPS) were mandated by the Energy Conservation Standards for New Buildings Act of 1976 to promote energy efficiency and the use of renewable resources in new buildings. The Department of Energy (DOE), in promulgating and implementing BEPS, is interested in a comprehensive strategy to complement BEPS and to further the national objectives of energy conservation and renewable resource use.

This report analyzes various policy instruments and strategies toward this end and concludes by recommending a comprehensive strategy. The main conclusions of this analysis are as follows:

- The effectiveness of the price mechanism has been greatly underrated in policy decisions. If the prices of oil, natural gas and electricity are allowed to rise through deregulation, decontrol and utility rate reform, the excessive use of energy would be discouraged, the supply of conventional energy sources would be enhanced, and the use of renewable resources would be encouraged. The impacts of rising energy prices permeate the entire economy and not just one or two sectors. The usual arguments against increased reliance on the marketplace are not persuasive. Any inflationary impacts are short-term. Indeed, the more efficient utilization of resources provided by the marketplace means that price decontrols are inherently counter-inflationary. The financial burdens imposed on the poor by high energy prices are easily lifted through direct income subsidies. Furthermore, these burdens are mitigated by the lower unemployment levels and higher incomes that result from the increased economic activity. Finally, deregulating energy prices could achieve a near optimal level of energy conservation as quickly or more quickly than a federal conservation program geared toward that end.

- In implementing BEPS, direct financial and administrative sanctions would not be appropriate at this time and could prove 
counter-productive. The reasons are that BEPS involves new concepts, computational tools, and institutional arrangements; many state and local governments may lack the expertise, funds and staff for adapting to the new conditions, especially those not currently enforcing an energy code. Furthermore, the housing industry is currently in a state of depression. If BEPS is to be implemented, federal financial incentives and technical assistance seem justified during the initial implementation period.

- The information, education and demonstration programs should play an important role in any strategy to promote energy conservation and renewable resource use.

- A tax and subsidy program should be used in conjunction with the decontrol and deregulation program. The tax, applied to imported energy and energy products, should be sufficient to reflect the social cost of national dependency on foreign $0 i l$ and natural gas. The subsidy program would protect low-income groups against the financial burden caused by higher energy prices.

- The level of Federal support for basic research, particularly in energy-related areas, should be increased. The fruits of this research could significantly reduce the nation's long-term energy problems.

From these considerations, a comprehensive strategy for encouraging energy conservation and promoting the use of renewable resources in buildings is proposed as follows:

- BEPS should be implemented with incentives and no sanctions for a period of two to four years; Congress should then evaluate BEPS' performance and act upon the basis of the results.

- The current phased program to decontrol oil prices should be maintained; the phased program to deregulate natural gas prices should be maintained or accelerated; and utility rate reform should be pursued by vigorously implementing the Public Utility Regulatory Policy Act (PURPA). 
- A tax should be applied to imported energy and energy products. The tax should be sufficient to reflect the social cost of national dependency on foreign $0 i 1$ and natural gas.

- A subsidy program should be implemented to protect low-income groups against the financial burden caused by higher energy prices. The subsidies should be in the form of income supplements, rather than direct energy subsidies, so that the recipients would also be encouraged to conserve energy.

- The level of Federal support of basic research should be increased, especially in energy-related areas.

- Information, education and demonstration programs should be adopted. Such programs should include a Building Energy Labeling program, a Technology Transfer Program, accelerated expansion of the Energy Extension Service, and the launching of a mass media campaign.

- A program should be adopted to encourage lending institutions to include expected utility bills in the expense-to-income ratio, which is used in evaluating mortgage applications.

The details of the conclusions and the recomended strategy are presented in Section 6 of this report. Other sections deal with the objective, scope and approach (Section 1), the criteria for evaluation (Section 2), the barriers to energy conservation (Section 3), and a description and assessment of the individual policy instruments and alternative energy strategies (Sections 4 and 5 ). The Appendix contains notes dealing with the relevency of Executive Order 12185 to BEPS (Appendix A) and with the inflationary impacts of policy instruments (Appendix B). 



\section{ACNOWLEDGMENTS}

This report was prepared for the Office of Conservation and Solar Energy, Department of Energy under Contract No. DE-AC06-76RLO 1830. Except for minor editing and corrections, it remains essentially the same as the final draft submitted to the sponsor on June 11980.

Many individuals have reviewed and provided constructive comments on earlier drafts of this report. Thanks are due Leslie Nieves, Tom Foley, Sue Balistocky, Steve Dunne, Archie Twitchell and Peter Back. However, the views expressed in this report are the authors' and we are the ones who are responsible for any errors that may have been left undetected.

Jeffrey $M$. Fang

Jack J. Tawil 


\section{CONTENTS}

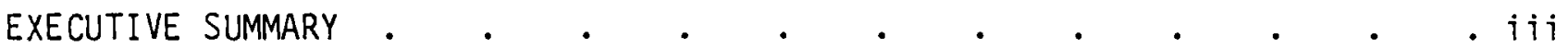

1. INTRODUCTION

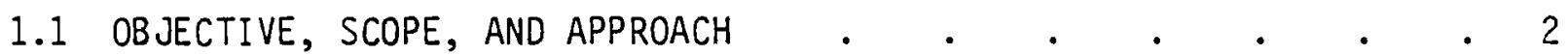

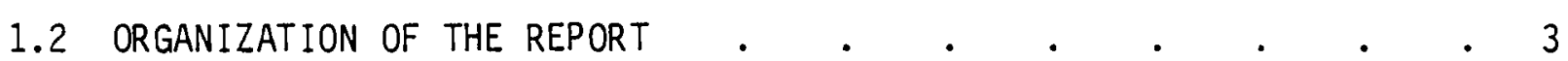

2. CRITERIA FOR EVALUATION

3. BARRIERS TO ENERGY CONSERVATION IN NEW BUILDINGS • $\quad$ • $\quad$ • $\quad$ • $\quad$ • 7

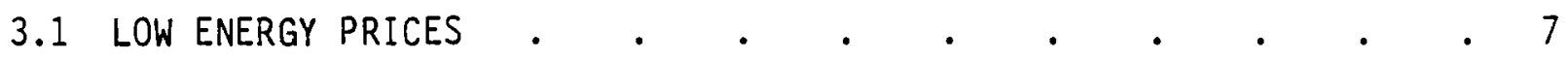

3.2 INADEQUATE INFORMATION $\quad$ •

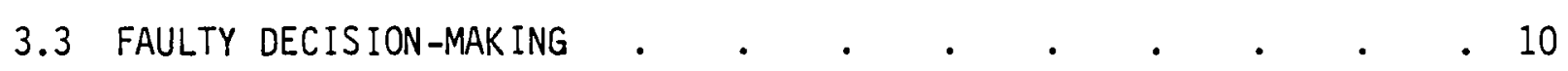

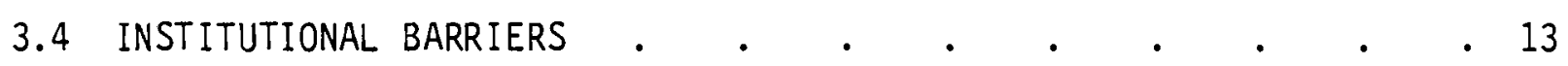

3.5 SUMMARY $\quad . \quad$.

4. DESCRIPTION OF POLICY INSTRUMENTS .

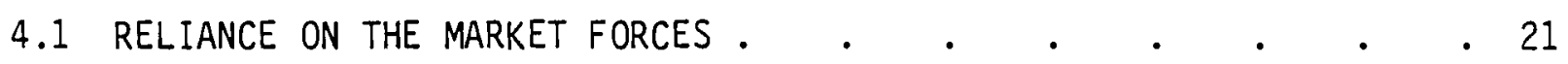

4.2 RESEARCH AND DEVELOPMENT .

4.3 INFORMATION/EDUCATION/DEMONSTRATION PROGRAMS . . . . . . . 31

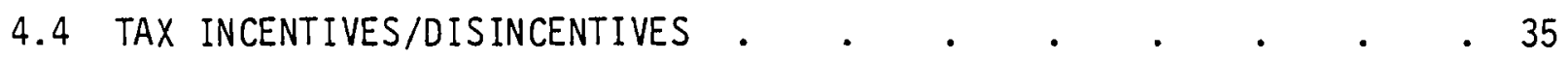

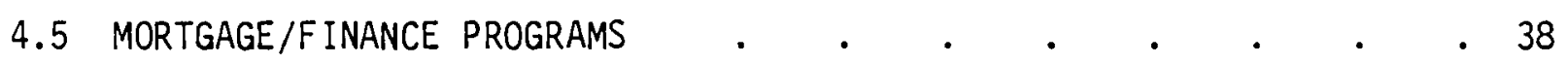

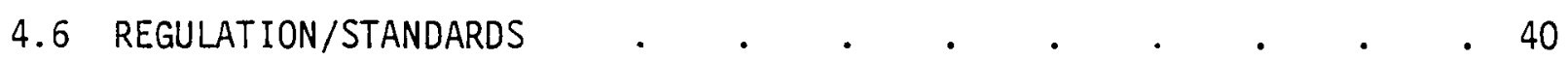

5. COMPARATIVE ANALYSIS OF FIVE ALTERNATIVE STRATEGIES • • • • • 47

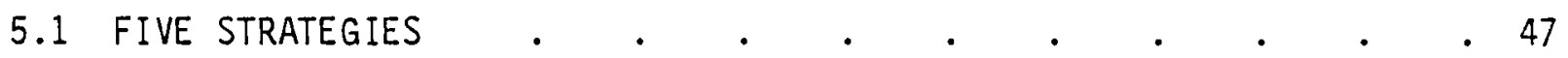

5.2 COMPARATIVE ANALYSIS OF THE ALTERNATIVE STRATEGIES \& • • • 49

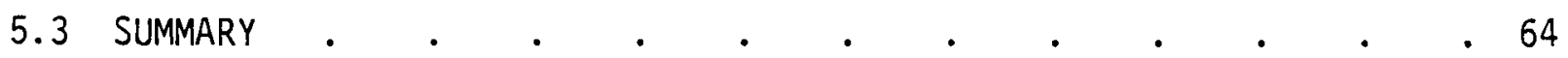

6. CONCLUSION

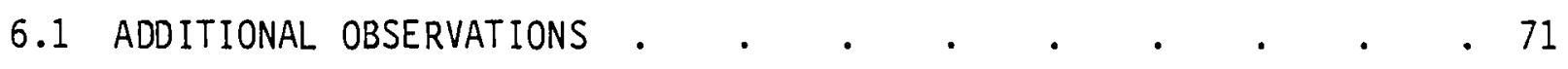




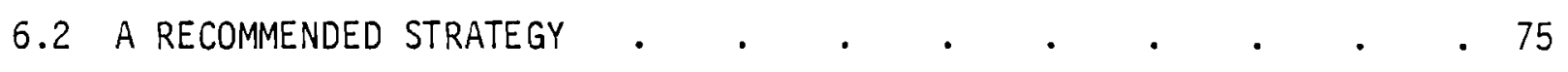
APPENDIX A - NOTE ON THE RELEVANCY OF EXECUTIVE

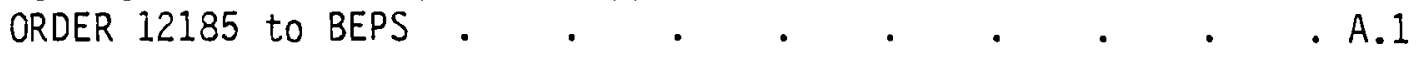

APPENDIX B - A NOTE ON INFLATIONARY IMPACTS . $. \quad . \quad . \quad . \quad$. $\quad$. B.I

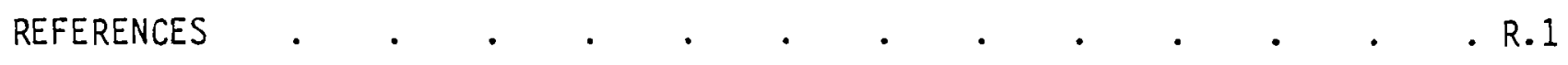




\section{INTRODUCTION}

The stock of residential and commercial buildings in the U.S. is both large and long-lasting. Currently, there are about 74 million residential housing units and $1.5 \mathrm{million}$ nonresidential buildings, and it is estimated that, by the year 2000 , about $60 \%$ of existing commercial units and $93 \%$ of existing residential units will still be in use. These buildings use large quantities of energy. In 1976, they consumed an equivalent of about 14.2 million barrels of $0 i 1$ per day, accounting for 38 percent of total primary energy consumption in the U.S. Over $80 \%$ of the total energy usage in buildings was for the purpose of space conditioning (heating, cooling, and lighting) and water heating (DOE 1979a). Thus, the production of buildings that are energy inefficient--in the context of current technology and present and expected energy prices--gives rise to significant, adverse energy impacts that persist over the useful lives of the buildings. Such impacts must be viewed seriously in light of the nation's precarious energy prospects and the national goal of reducing dependency on energy imports.

With these concerns, Congress enacted the Energy Conservation Standards for New Buildings Act of 1976 (Title III of Energy Conservation and Production Act $(E(P A))$ to promote energy efficiency and the use of renewable resources in new buildings. Specifically, the purposes of the Act are to:

(1) redirect federal policies and practices to assure that reasonable energy conservation features will be incorporated into new commercial and residential buildings receiving federal financial assistance;

(2) provide for the development and implementation, as soon as practicable, of performance standards for new residential and commercial buildings which are designed to achieve the maximum practicable improvements in energy efficiency and increases in the use of nondepletable sources of energy; and

(3) encourage states and local governments to adopt and enforce such standards through the ir existing building codes and other construction control mechanisms, or to apply them through a special approval process. 
Congress adopted the regulation/standards approach in ECPA by mandating building energy performance standards (BEPS) for new buildings to meet its broad intent of achieving the maximum practicable improvement in energy efficiency and the utilization of renewable energy resources in new buildings. The Department of Energy (DOE), in acting on the appropriate portions of ECPA, has issued the Notice of Proposed Rulemaking, conducted public hearings, and will issue the final rule, including its implementing regulations, in the near future. However, the federal government is also interested in strategies that would supplement BEPS in achieving the objective of energy conservation and utilization of renewable resources.

\subsection{OBJECTIVE, SCOPE, AND APPROACH}

This report analyzes alternative federal strategies and their component policy instruments and recommends a strategy for achieving the goals of the Act. In this analysis the concern is limited to space conditioning (heating, cooling, and lighting) and water heating. The policy instruments considered include greater reliance on market forces; research and development; information, education and demonstration programs; tax incentives and sanctions; mortgage and finance programs; and regulations and standards.

The analysis starts with an explanation of the barriers to energy conservation in the residential and commercial sectors. Individual policy instruments are then described and evaluated with respect to energy conservation, economic efficiency, equity, political impacts, and implementation and other transitional impacts. Five possible strategies are identified and a comparative analysis is performed. Finally, based upon the authors' professional judgment, elements are proposed for inclusion in a comprehensive strategy for conservation in new buildings.

Due to time and resource constraints, much of the evaluation is qualitative in nature, although some quantitative results are cited from existing studies and published reports. 


\subsection{ORGANIZATION OF THE REPORT}

The following section (Section 2) establishes the criteria for assessing the relative effectiveness of the options. Section 3 provides an overview of the major barriers to conservation and renewable resource utilization in new buildings. Available policy instruments are then outlined in Section 4 . Five strategies are defined and comparatively evaluated in Section 5 . Section 6 concludes the report by sumarizing the analys is and recommending an effective strategy. Appendix A addresses relevancy of Executive Order 12185 to BEPS and Appendix $B$ provides additional discussion on the inflationary impacts of policy instruments. 


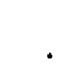




\section{CRITERIA FOR EVALUATION}

In order to assess the effectiveness of various policy instruments for achieving a proper level of conservation in new residential and commercial buildings, criteria must be established and applied. The major criteria that will be used to evaluate these policy instruments are: (1) energy conservation, (2) economic efficiency, (3) equity, (4) political impacts, (5) implementation impacts, and (6) other transitional impacts. While inflation impacts are of major concern, such impacts are given only in obvious cases for reasons explained in "A Note on Inflationary Impacts" (Appendix B).

Energy conservation is really one aspect of economic efficiency. However, since energy conservation is a central concern of this report, it is treated as a criterion apart from economic efficiency.

Economic efficiency relates to ( 1 ) the allocation of goods and services among individuals (distributive efficiency), (2) the use of resources (inputs) to produce goods and services (production efficiency), and (3) the intertemporal distribution of goods, services and resources (inter-temporal efficiency). An allocation that is distributive-efficient implies that no reallocation can make an individual better off without, at the same time, making other individuals worse off. Production efficiency implies that no reallocation of inputs can produce a higher-valued output. Finally, intertemporal efficiency implies that the flow of output over time describes an optimal (highest-valued) path. Thus, economic efficiency provides an optimal allocation among individuals, in the choice of output and methods of production, and in the flow of output over time.

It is known from economic theory that a perfectly competitive economy provides efficient resource allocation. In the real world, however, economies diverge from this competitive ideal, and for several reasons. Economies may, for example, not be sufficiently competitive; there may be resources (such as clean air) which are not transacted through markets, thus giving rise to externalities; there may be information which, if provided, would result in further beneficial economic activity; and there may be institutional barriers (such as government-imposed market restrictions) which hinder attainment of the competitive ideal. 
In applying the efficiency criterion, then, we must also consider a policy's effect on market competition, its effect on externalities, the extent to which it fosters beneficial economic activity by providing useful information to the marketplace, and the extent to which institutional changes created by the policy raise or lower barriers to beneficial market activity.

Equity considerations must also play a role in policy evaluation. An economically efficient policy may give rise to income and wealth distributions which are unacceptable to society as a whole. However, this in itse lf is not a sufficient reason for rejecting such a policy, for there are means (such as the income tax) that can be effectively applied to redistribute income and wealth. In general, economically efficient policies provide larger total incomes; they therefore offer greater redistributional opportunities. A problem may occur, however, when a policy gives rise to significant costs or benefits that are outside (external to) the market and therefore affect well-being without affecting incomes. Environmental effects often fall into this category. Such effects must then be weighed against the income effects to arrive at a desirable policy decision.

Another equity consideration concerns the level of unemployment. The most efficient policy need not be the policy which minimizes unemployment. To the extent that society is willing to sacrifice some real income to achieve a given decrease in unemployment, a more efficient policy may be less desirable than a policy providing lower unemployment.

In a society where a policy must meet the tests of the legislative and executive branches of government, the political impacts of the policy are highly relevant. Political expediency sometimes dictates that an otherwise less desirable policy be proposed, given the relative chances for adoption.

Finally, implementation impacts and other transitional effects of a policy must be evaluated. A policy that is clearly beneficial once it is in place may be unacceptable because implementing the policy is too costly or otherwise infeasible. Similarly, an attempt to attain the benefits from a policy too quickly may be counterproductive because transitional effects are severe. Often a phase-in period is desirable so that affected parties can adjust to the new political, social and economic environment resulting from the policy. 


\section{BARRIERS TO ENERGY CONSERVATION IN NEW BUILDINGS}

Before examining existing barriers to energy conservation in new buildings, it is useful to establish a benchmark from which to gauge existing conservation levels. An appropriate benchmark is the optimal level of conservation. Divergencies of existing conservation levels from optimal levels are indicative of conservation barriers.

While there is opportunity for disagreement on the optimal level of conservation in new buildings, we will take as the optimum that level at which the marginal improvements in building conservation have a social cost equal to the present social value of the energy savings, other things, such as comfort levels, building functional efficiency and aesthetics, remaining the same. This level of conservation is consistent with that of minimizing social lifecycle costs, the same criterion employed to derive energy performance standards for new, single-family housing in DOE's proposed rule.

Possible barriers to energy conservation in new buildings to be considered are (1) energy prices which undervalue the social worth of energy, (2) inadequate information on which to base conservation decisions, (3) faulty decision-making by consumers, and (4) institutional barriers to optimal energy conservation.

\subsection{LOW ENERGY PRICES}

Prior to World War II, oil and natural gas prices in the U.S. were determined largely by market forces. Major oil discoveries in the Gulf States and a relatively low world demand for petroleum products resulted in low and often declining oil prices. Natural gas was commonly "flared off" at the wellhead, since the pipeline network to distribute the gas to end users was quite limited. Electricity prices were also low and declining during this era as a result of exploitation of the considerable economies of scale in electricity generation.

In 1938, Congress passed the Natura 1 Gas Act, bringing interstate pipelines within the regulatory control of the Federal Power Commission (FPC); and in 1954, the Supreme Court ruled, in Phillips Petroleum Co. v. Wisconsin, that 
the FPC also had regulatory authority over the wellhead price of natural gas. Until 1970, however, the regulated interstate market price maintained close parity with the intrastate free market price.

0 il prices did not come under federal control until 1971, when they were frozen by President Nixon's wage and price controls. When these controls were subsequently lifted, oil prices were not included.

Electricity prices bottomed out around 1960, after the scale economies in generation had been largely exploited. From then on, utilities faced increasing generation capacity costs, but these did not increase sharply until the early Seventies [EPRI 1979, p. II-52]; and utility operating costs, which depend primarily on fuel prices, did not escalate sharply until the OPEC oil embargo in 1973 sent fuel prices skyrocketing.

It was not until the early 1970's, then, that oil, natural gas and electricity prices began their steep ascent. Prior to this period energy was relatively cheap and abundant, and the optimal level of energy conservation for buildings and other commodities was very low by today's standards. Not surprisingly, buildings were constructed with little, if any, insulation, and automobiles were built more for performance than for fuel economy.

As the social value of energy increased in the 1970's, the retail price of energy--whether $0 i 1$, natural gas or electricity--did not keep pace due to continued control and regulation; and even the high prices today for these resources are below their optimal prices. (a)

(a) The optimal price, which expresses the social value of the resource, may be higher or lower than a market-clearing price for two reasons. First, production of the commodity may cause externalities, so that the social benefit (cost) does not equal the private benefit (cost). An example is a commodity the production of which causes environmental damage. In this case, the private costs of the commodity (its price) are less than the social costs (optimal price). Second, a price may be high enough to clear present markets, yet be too low to ensure an adequate future supply. Rent controls are a good example of this situation. When rent controls are first imposed, the supply of rental housing is sufficient to satisfy the demand at the controlled price. Eventually, however, resources are withdrawn from rental housing and invested in endeavors yielding a higher rate of return. The inevitable result is a rental housing shortage after a few years of controls. 
There are two other consequences of artificially low prices, and these have serious, long-term implications. Compared with optimal prices, low prices mean lower rewards (profits) for those who would search out new supplies of the price-controlled resource, and a reduced search effort is likely to result in a smaller future supply. Secondly, lower prices mean lower rewards to those who would discover new energy-saving technologies and oiland gas-saving substitutes. Consequently, the search for these will be less intense, and the prospects for future innovations and substitutes less favorable.

In short, energy prices below the optimal level lead to too little energy conservation, and, by discouraging future energy supplies and energy-saving techniques, they make the need for future--and costlier--conservation even greater.

\subsection{INADEQUATE INFORMATION}

Information is a basic ingredient in the decision-making process. The better the information, the better is the resulting decision likely to be. However, because information is usually costly to obtain, the decision maker will generally not seek it if its expected benefit does not exceed its cost (in terms of time, effort and expense).

This concept is readily illustrated by the prospective home buyer. If energy prices are relatively low, space-conditioning costs will be a relatively unimportant item in $h$ is budget, and information that would enable him to reduce his energy use by a given amount might have relatively small value to him. Let energy prices rise, however, and such information becomes increasingly valuable to him.

The recent surge in energy costs and the resulting increased demand by the home buyer for energy-related information gives witness to this phenomenon. Today's home buyer appears to be increasingly knowledgeable about R-values, glazing, house orientation, and even solar techniques. The buyer of a used home now often requires a recent history of the seller's utility costs. 
In response to the home buyer's increased demand for information, there has been a tremendous growth in the amount of information readily available to him. Many builders now actively promote the energy-saving features in the homes they are constructing. Sales and library loans of books on solar housing have increased sharply, and new energy-saving materials and devices are widely advertised. This demand for and supply of energy-related information are a direct response to dramatically increased energy costs. Similar responses are observable with respect to commercial and industrial buildings.

Energy-related information, while growing rapidly, is probably still inadequate, given today's social value of energy. While today's home buyer may be aware, for example, that more insulation is better, he usually does not know the amount by which added insulation will reduce $h$ is space-conditioning costs. That is, the information that would allow him to equate the marginal cost of conservation with the (present value of the) expected energy savings is not usually available to him.

A related problem concerns the reliability of the available information. While many claims are made about the energy-conserving potential of materials, building techniques and equipment, consumers have learned to view such claims with some skepticism. Validation of these claims by credible sources will increase the consumer's willingness to believe and act upon them.

\subsection{FAULTY DECISION-MAKING}

A possible barrier to achieving the optimal level of energy conservation concerns faulty decision-making on the part of the consumer. Consumer decisions could be faulty for several reasons: (1) the decision may be based on false or inadequate information, (2) the risks associated with the decision may be improperly assessed, (3) uncertainty about the future may result in bad judgment about future energy prices, new technologies and future income, (4) social costs and benefits diverge from private costs and benefits, yielding bad decisions from society's standpoint, (5) in assessing the present 
value of costs and benefits, an erroneous discounting factor could be (implicitly) used, and (6) the consumer could be inept at making decisions, even with perfect information.

The problem of false or inadequate information has already been discussed in the previous section. Presumably, the wide dissemination of accurate and credible information would largely remove this potential source of decision error.

Risks associated with the decision relate to maintenance costs, improper construction and/or installation, premature equipment failure and casualty losses. Health and safety risks may also be involved. Improper risk assessment can lead to a faulty decision: underrating the risks will cause over investment in conservation, while overrating the risk will cause under investment.

Uncertainty about the future has a strong effect on the decision process. The expected course of future energy prices, for example, directly affects the net present value of an investment in energy conservation: higher expected prices yield higher net present values. Uncertainty about yet-to-be-developed technologies exposes the purchaser to the risk of obsolescence. This risk can be illustrated by the purchase of a solar water heater. Given the extensive research and development currently taking place in the active solar area, the purchaser runs the risk that, in a few years, the same solar capability can be acquired at a small fraction of its current cost. The result is a future capital loss. (Those who purchased calculators and computers a few years ago have indeed suffered such capital losses.) Finally, the purchaser's uncertainty about his future income can also affect his decision. The higher the uncertainty, the less willing he may be to invest in an asset which cannot be easily liquidated without heavy financial loss.

Judgments about the future are implicit in the decision-making process. Yet the essence of future uncertainty makes it difficult to assess an individual's judgments about it. Hindsight informs us of the accuracy of these judgments, but improbable events happen continually and make it difficult to 
separate the elements of luck from those of good judgment. (A record of consistently accurate forecasts, however, is more indicative of good judgment than of luck.) While it may be presumptuous to be critical of an individual's assessment of the future and, hence, $h$ is decisions, research conducted on future conditions could help the individual to assess the future.

To the extent that social benefits (costs) diverge from private benefits (costs), private decisions may achieve a private optimum, but they will depart from the social optimum. However, as will be explained in Section 4, appropriate policy instruments can be applied to correct for th is imbalance.

Let us consider now the proposition that consumers often err by discounting the future too heavily. To assess this proposition, it is important to note that an appropriate discount rate depends not on ly on the fact that income received now is worth more than the same income received at a future date, but on risk and uncertainty as well. Higher perceptions of risk and uncertainty are commensurate with higher subjective rates of discount. In addition, preferences for risk vary among individuals, which, for example, helps to explain why some individuals insure against loss while others do not.

To demonstrate, then, that some persons discount the future too heavily, one must show that either they incorrectiy perceive the risks or unreasonably assess the future. Disagreement falls far short of demonstration. Furthermore, criticizing a person's preference for risk is as valid as criticizing his preference for, say, apple pie.

From the preceding discussion, it should be clear that faulty decisionmaking by the consumer should not be lightly assumed. The essence of future uncertainty, the difficulty of assessing risk, and differences in the preference for risk all result in legitimate variations in consumer behavior.

Recent evidence submitted at the public hearings on BEPS suggests that many consumers are responding to higher energy prices by demanding more energy-efficient housing. Reliable information will improve this response by lowering risk to the consumer. A case in point is the apparent widespread use 
of EPA mileage estimates in consumer decisions regarding new car purchases. All of this suggests that many consumers are competent to synthesize the ingredients of decision-making into reasonable decisions.

On the other hand, we do not have a good record of consumers who are apparently making unreasonable decisions, given the information available to them. Further research needs to be conducted in this area to indicate more precisely how widespread is the phenomenon of reasonably good decision-making.

Before considering other barriers to energy conservation, one other point is worth making. In comparing private risk with social risk, we find that society as a whole benefits because consumers do not agree in their assessment of risk and evaluation of the future. What this means is that the impacts of the future on society tend to be moderate, even though some individuals will experience large gains while others experience large losses. Under a program (such as BEPS) where a single assessment of risk and a single forecast of the future are used to make a decision that is then imposed on all (new-home buyers), the possible outcomes of both a very large benefit and a very large loss to society are greatly enhanced, while moderate outcomes become much less likely.

\subsection{INSTITUTIONAL BARRIERS}

There are a number of possible legal and institutional barriers to achieving an optimal level of energy conservation. Among these are (1) legally controlled energy prices, (2) utility regulatory practices, (3) externalities in the production and use of energy, (4) state and local building codes, (5) lending practices of financial institutions, (6) the tax structure, (7) institution-induced increases in market risk, and (8) the speed with which the market adjusts to changed supply and demand conditions.

The adverse effects of controlled energy prices on conservation have already been discussed. However, it is useful to elaborate on the effect on energy conservation of utility regulatory practices, particularly those relating to price and supply. 
As we have already noted, the generation of electricity, prior to around 1960, was characterized by decreasing average costs (economies of scale). Since marginal-cost pricing would have required electric utilities to operate at a loss, it was appropriate to adopt some alternative pricing scheme. The scheme to emerge was average-cost pricing, which allowed, but did not guarantee, utilities a "fair" rate of return on their invested capital (rate base). Declining-block rates were offered to customers and justified on the grounds of increasing returns to scale.

After 1960, however, the scale economies in generation largely disappeared and, with them, the justification for average-cost pricing and declining-block rates. Notwithstanding these changed economic conditions, state regulatory practices have, with few exceptions, been unresponsive.

Under increasing cost conditions, economic efficiency dictates marginalcost pricing. Since most electric utilities now operate under increasing cost conditions but price according to average cost, their prices to customers are too low and, consequently, encourage over-consumption of electricity. Declining-block rates further encourage this. Thus, current regulatory practices hinder the efficient use of electricity and discourage conservation.

Externalities associated with the production and use of energy may also be contributing to excessive energy use. Both the production and use of energy adversely impact the environment. Imposition of costly environmental controls have internalized these social costs to a large degree, but some external costs remain. On the other hand, there is ample reason to believe that the costs of controls have been excessive; that is, the same environmental benefits could have been achieved at far less cost. (See, for example, Baumol et a1., 1979) In light of this, it cannot be confidently concluded that energy use is excessive because it fails to include all environmental costs.

Another externality that clearly has resulted in excessive energy consumption arises from the use of master meters to measure electricity use. (Master meters are meters that measure the combined electrical consumption of two or more households. Thus, increased electrical use by one individual must 
be paid for by all households on the meter.) Master meters are largely the product of by-gone days when electricity (and natural gas) was relatively cheap and meters expensive. Costs were minimized by economizing on meters at the expense of higher electrical use. With current energy costs, master meters work against the interest of both the utility (for reasons not discussed here) and the customer.

State and local building codes present another barrier to energy conservation. Such codes are almost always prescriptive; that is, they specify the techniques, materials and equipment that must be incorporated into a building. In many jurisdictions, if new energy-saving products become available in the marketplace, they cannot be used until the code is revised. The willingness of a jurisdiction to revise its code varies from place to place, but the process can be lengthy and costly, and the outcome is often uncertain.

Furthermore, because the sale of new, energy-saving products may depend on the willingness of local jurisdictions to alter the ir codes, the revision process almost certainly reduces the rate at which new products are introduced.

Prevalent lending practices of financial institutions also present a barrier to energy conservation. Today's lending practices still largely reflect the era of cheap energy, when energy bills constituted a relatively minor item in the home owner's budget. Essentially, the energy efficiency of a mortgage applicant's prospective home is presumed not to affect his ability to repay $h$ is mortgage, at least in a measurable way. Thus, while energy efficiency increases the initial cost of the home, little or no consideration is given to the fact that the applicant's energy bills will be lower, thus increasing $h$ is credit-worthiness. Some lending institutions have defended the ir current practices by claiming that their experience with buyers of energy-efficient housing has been too recent to assess the impact of energyefficient housing on the borrower's ability to repay his mortgage. Furthermore, today's unsettled housing market conditions and the restricted supply of mortgage money may, for the time being, discourage financial institutions from changing their lending practices. 
The existing tax structure is viewed by some as a barrier to energy conservation. Local property taxes are assessed on the value of real property, including improvements. To the extent that improvements in energy efficiency add to the value of the property, these improvements are also taxed. (Some jurisdictions, such as California, exempt certain types of improvements, such as active solar additions, from sales and/or property taxes.) While removing such taxes will encourage energy conservation, the economic justification for such exemptions is not clear, particularly if consumers are required to face optimal energy prices. (a)

At the national level, tax policy is generally favorable or neutral with respect to energy conservation. The tax deduction for gasoline consumption has been removed for most use categories, including gasoline consumed on

(a) The distributional impacts of local tax incentives for energy conservation are worth noting. The following numerical example is instructive. Assume the local community subsidizes half the cost of an energy-efficient improvement costing $\$ 120$. Foregone tax revenues equal $\$ 60$, which are lost to the community in public services. The recipient of the subsidy values the energy-saving device at less than $\$ 120$, say $\$ 95$; otherwise he would have purchased the device anyway, making the subsidy unnecessary for the purchase. If the energy saved by the subsidy recipient has a market value of $\$ 100$, the balance sheet is as follows:

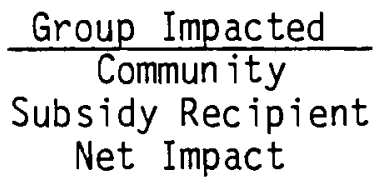

Group Impacted

Subsidy Recipient

Net Impact

(The difference in the value of the energy saved (\$100) and the value of the device to the purchaser $(\$ 95)$ is $\$ 5$ and can be viewed as a risk premium.) If the energy saved has a social value of less than $\$ 125$, the net social impact is negative for the nation as a whole. If the social value equals $\$ 125$, the net impact on the nation is zero (excluding the social cost of resources required to administer the subsidy); but in this case, the community has transferred $\$ 25$ of its wealth to the nation.

Finally, if the social value of the energy saved is greater than $\$ 125$, the net impact on the nation is positive, but the community is still $\$ 25$ poorer. Thus, even if the social value is greater than $\$ 125$, the local impact suggests that the corrective policy should take place at the national level, rather than at the local level. Finally, let it be noted that the effect of the subsidy within the community is probably regressive, since the beneficiaries of the subsidy are likely to be more affluent than the would-be recipients of the public services foregone. 
public roads and highways by pleasure vehicles. Tax credits are now given for several categories of investment in energy efficiency; and, although energy costs are still deductible as a legitimate business expense, it is difficult to see how this deduction could be disallowed without creating major inequities among businesses, given their varying degrees of reliance on energy inputs.

Other barriers to energy conservation may exist because of institutioninduced risk. Liberalization of product liability laws by the courts have apparently had a significant impact on the willingness of manufacturers to introduce new products to the marketplace. Those new products that are introduced are more expensive because product liability insurance premiums have escalated sharply in recent years to reflect the increased risk to the insurer. Environmental and safety regulations have also increased the risk and cost of introducing energy-saving products. No position is taken here regarding the appropriateness of these barriers; rather, they are only identified as reducing the flow of new, energy-saving materials and equipment or increasing their costs.

Finally, the speed with which the marketplace adjusts to changing supply and demand conditions is sometimes viewed as a barrier to energy conservation. According to this view, the response of the market is slower than what could be effected by government mandate. Although government mandate might effect faster energy savings, it should be noted that the built environment and other measures of social welfare will be different from what would have occurred in the marketplace without government intervention, thus making it difficult to compare the two policies. For example, federal requirements for energy conservation in new buildings will result in more conservation for some households (given their assessment of and preference for risk, etc.) and less for other households (who may assume, because of the Standards, that stricter conservation is not cost-effective for them) than would occur in an unrestricted marketplace. A uniform standard cannot, by its very nature, reflect the preferences of all people, whereas the marketplace does permit the freedom which enables individual preferences to be satisfied. Two questions are raised here: (1) If the marketplace can achieve a given savings in energy in so 
many years, can government mandate achieve this result more quickly?

(2) Given a positive response to the first question, is the time saved worth the added cost of a large number of consumers being made worse off (from their own perspective)? The answer to the first question may depend on whether the government itself provides reliable information to the marketplace, and whether consumers will be required to face optimal energy prices. The second question is left unanswered.

\subsection{SUMMARY}

Perhaps the single greatest barrier to energy conservation has been the control of $0 i 1$ and natural gas prices. The private cost of energy to consumers has fallen far short of the social cost because of such controls; and individual decisions are made on the basis of private costs. Furthermore, unrealistically low energy prices depress domestic levels of oil and natural gas output, retard the search for new energy sources, and discourage the search for both energy-saving products and substitutes for $0 i 1$ and natural gas.

Accurate and credible information is a major ingredient in the decisionmaking process. Since energy prices began their steep ascent in 1973, information on energy efficiency has been increasing at a rapid pace. Recent evidence reinforces the view that consumers are utilizing this information to make energy-saving decisions. However, there may still be a number of areas in which valuable information is not readily available to the consumer.

The view that consumers, given adequate information, suffer from unreasonably defective decision-making is not easy to demonstrate. Because risks are often difficult to assess and future events are hard to foresee, individual decisions are usually defensible, even when hindsight shows the decisions to be costly. Additionally, varying preferences for risk also cause decisions to differ.

A number of potential institutional barriers to energy conservation have been identified. Those whose removal shows the greatest promise of energy savings are energy price decontrol and utility regulatory reform. However, 
there are equity questions that need to be addressed. Other barriers, such as state and local building codes and lending practices of financial institutions suggest some potential net benefits with appropriate policy instruments. Still other barriers, such as product liability laws and environmental and safety regulations might be considered, but strong consideration should be given to potentially adverse side effects. 


\section{DESCRIPTION OF POLICY INSTRUMENTS}

There are various policy instruments available for dealing with barriers to energy conservation and use of renewable resources in new buildings, as explained in Section 3. Some of these change the effective prices of energy to consumers, either by providing subsidies and tax incentives for energy conservation, by imposing tax penalties on energy consumption, or by allowing the price mechanism to work more independently. Some seek to stimulate new conservation technologies through research and development. Others attempt to improve consumer decision-making by providing information, to facilitate the adoption of technology into new building design and construction, and to affect financing arrangements. Still other policies dictate the specifications of buildings and appliances installed in the buildings through codes, standards and regulations.

For our purpose, the relevant policies can be grouped into six categories: greater reliance on market forces, imposition of regulations and standards, stimulation of research and development, dissemination of information and implementation of education and demonstration programs, application of tax incentives and sanctions, and modification of mortgage finance programs. Each category contains several possible instruments, each of which will be evaluated in terms of the criteria discussed in Section 2.

\subsection{GREATER RELIANCE ON MARKET FORCES}

In a perfectly competitive economy, where all goods and services are priced at their respective marginal costs, economic efficiency is achieved. Although this competitive ideal is not attained in practice, our earlier discussion on energy prices and their effect on energy consumption strongly suggests that greater economic efficiency would result from decontrol of $0 i 1$ and natural gas prices and marginal-cost pricing for electricity. The policy instruments that would foster this end include maintaining the current, or an accelerated, timetable for $0 i l$ and natural gas price deregulation and utility rate reforms. 


\subsubsection{The Current Policy}

The current schedule for deregulation of domestic crude oil allows the price of controlled oil to increase at a certain rate per month, beginning in January 1980 , so that by October 1981 price controls will be completely removed (44 FR 66186, November 19, 1979). Similarly, the Natural Gas Policy Act (NGPA; PL 95-621) gradually relaxes all federal price regulation on natural gas, with nearly complete deregulation to be achieved by 1985 . Prices of natural gas and petroleum products will eventually rise to some marketclearing level; and since natural gas and oil are used in some places to generate electricity, increases in electricity prices can also be expected. With the prospect of rising prices of fuels and electricity, there will be more incentive to buy and/or build houses and commercial buildings with better thermal integrity, to insta 11 more efficient space conditioning and water heating equipment, to adopt more energy-efficient use patterns, and to adopt alternative energy resource systems. Therefore, it would seem that, on efficiency grounds, the current decontrol/deregulation plan would gradually foster conservation and promote the use of renewable energy resources.

One provision of NGPA needs to be noted. Under its implementing rules, higher natural gas prices will be imposed first on industries using natural gas as boiler fuels, and then on all other industrial users. (a) Residential and commercial users of natural gas are initially to be shielded from the full impacts of price deregulation (Title II of NGPA and 44 FR 67170, November 23, 1979). The net result of this provision is to delay the expected conservation impacts on residential and commercial users of natural gas until after 1985. Nevertheless, the anticipation of complete deregulation--and higher gas prices--after 1985 would still provide a major incentive to achieve better thermal integrity and to install more efficient equipment and appliances in buildings, because of their long, useful life.

With respect to the impact of the current deregulation plan on competition, reduced government intervention is likely to stimulate competition for two reasons. First, reduction of the regulatory compliance burden will

(a) At the time of this writing, Congressional action appears likely to delay the implementation of this provision. 
stimulate market entry by small firms. Second, decontrol of prices will, in the short run, give rise to high profit levels. Attracted by these profits, new firms will enter the market to supply conventional and unconventional energy sources. This, in turn, will increase the competitive pressures on profits.

The advantages of the option of implementing current decontrol provisions are that the legal framework is already in place, the rules are being formulated, and we find no significant conceptual difficulties in terms of implementation. Politically, there is likely to be resistance among some groups that are opposed to higher energy prices and who perhaps believe that they would do better under some alternative, such as energy rationing. (While many individuals might be better off under rationing, the value of total output would be less than under price decontrols, other things remaining the same.)

The equity impacts are a major weakness of this policy alternative. Higher energy prices can impose a heavy financial burden on lower-income groups. However, existing programs are designed to ease such burdens, and a significant portion of revenues from the "windfall profits" tax is currently earmarked to shield the poor from the effects of higher energy prices.

\subsubsection{Accelerated Deregulation}

As mentioned, domestic crude oil prices are scheduled to be decontrolled by October 1981 and natural gas prices by January 1985. Both processes are phased to minimize disruptions. 0il price decontrol is to be carried out over a 22 -month period, and it is probably undesirable, if not impossible, to accelerate this schedule. In contrast, natural gas deregulation is a 5-year process. Hence, there would appear to be more latitude for moving the timetable ahead either by new legislation, or by invoking Section 202 of NGPA. Section 202 can be applied to expand the coverage of incremental pricing to other industrial uses, and to make residential and commercial users bear a larger burden of the price increases. From the point of view of conservation in new buildings, the last option is probably the more significant one. 


\subsubsection{Utility Rate Reforms}

While utility rate reform does not, strictly speaking, place more reliance on the market place, it does offer the opportunity, through regulation, to present consumers with the same or similar price signals that they would face in a perfectly competitive market for electricity and natural gas. For this reason, it is included in this section.

The current federal policy concerning retail utility rates is covered under the Public Utility Regulatory Policy Act (PURPA, PL 95-617). The act establishes three federal "purposes"--energy conservation, efficient use of utility resources and facilities, and equitable rates to consumers--and prescribes a series of federal standards to help attain them.

Each state regulatory commission or nonregulated electric utility is required to make "considerations and determinations" concerning six ratemaking standards:

1. Cost of Service - Rates should be designed to reflect cost of service to each class of customer.

2. Declining-Block Rates - Unless it can be demonstrated that the cost of providing energy declines for a class of customers, declining-block rates for energy are prohibited.

3. Time-of-Day Rates - Time-of-day rates should be charged to each class of customer, unless it is not cost-effective to do so.

4. Seasonal Rates - Rates should reflect any seasonal fluctuations in cost of providing service to each class of customer.

5. Interruptible Rates - Interruptible rates should be offered to industrial and commercial customers commensurate with the costs of providing this type of service to each class of customer. 
6. Load Management Techniques - Load management techniques should be offered to a utility's customers subject to a determination by its state regulatory commission or, if unregulated, by the utility itse lf that such techniques are practicable, cost-effective, and reliable.

The state regulatory authority or nonregulated electric utility is further required to adopt, by a certain date, five federal standards which, together,

- prohibit or restrict master-metering under certain circumstances

- outlaw automatic adjustment clauses unless certain conditions are met

- require conveying rate schedules, customer classes, and other relevant information to the utility's customers

- forbid the utility to terminate service to any customer unless certain requirements are satisfied

- establish that shareholders (or other owners) of the utility, and not its customers, pay for the direct and indirect costs of promotional and political advertising.

The state regulatory authority or the nonregulated utility is also required to conduct a full evidentiary hearing on "life-line" rates, as an exception to the cost-of-service standard. The process of considering, determining, and/or adopting these standards by the state regulatory authority or the unregulated utility should be kept open, objective, and systematic. Moreover, federal and consumer participation in such process should be ensured.

Most of the federal standards on retail rate-making, such as cost of service, declining-block rates, time-of-day rates, seasonal rates, interruptible rates, load management techniques, master metering, automatic adjustment clauses, consumer information and advertising address directly the issues of energy conservation and efficient use of resources, including marginal-cost pricing. These standards would tend to force state regulatory authorities 
or unregulated utilities to consider incremental cost pricing and make decisions that are, at the very least, not contrary to the idea of utilizing the market mechanism to provide the correct price signals to electricity consumers. The standards on termination of service and lifeline rates deal with equity concerns. Moreover, both efficiency and equity are promoted by the advertising, automatic adjustment clause, and consumer information standards.

In enacting PURPA, Congress chose not to impose a rigid system of federal regulation; instead it provides only the overall framework and allows the state regulatory authorities to consider local conditions in improving the utility regulatory process. The tools available to the federal government under PURPA include informal discussions with staff of state regulatory commissions and unregulated utilities, formulation of implementing rules, and review of reports submitted by state commissions and utilities. However, the rights to participate and intervene in individual rate-making proceedings and to seek judicial reviews of state actions are also a part of PURPA.

With in PURPA, the following actions appear possible:

- To achieve the benefits from market forces more quickly, the Economic Regulatory Administration (ERA) should adhere to the time limitations set forth in the legislation for adopting implementing rules and regulations. Where possible under the law, it might be desirable to accelerate this process.

- Frequent staff contacts with appropriate regulatory authorities and utilities should be made to ensure that states and utilities cooperate in implementing PURPA.

- Principles of marginal (or incremental) cost pricing should be promoted to provide utility customers with the correct price signals, so that they will use energy efficiently.

- Direct subsidies should be encouraged as an alternative to lifeline rates, as the latter may adversely affect conservation and efficiency. 
- The ERA should, when the public interest dictates, actively intervene in utility rate-making proceedings to promote the objectives of PURPA.

Some potential implementation problems involve adopting operationally useful definitions of "marginal cost pricing" and "cost of service." Furthermore, adoption of time-of-day and seasonal rates could cause the peak to shift without adequately lowering it, necessitating further rate adjustments. However, such problems appear solvable.

As PURPA is implemented, political resistance could be encountered from state and local interests, the complaint being usurpation of states' rights in retail utility rate-making. Presumably, such arguments have already been aired during the enactment process. Moreover, potential resistance may be tempered because, under PURPA, major state initiatives are allowed.

\subsubsection{Summary}

Market forces can be a powerful instrument for enhancing societal we 1fare. To capture the benefits that are offered by greater reliance on the marketplace, the following policies should be vigorously pursued:

- Crude 0il Price Decontrol - Continue the current phased decontrol timetable, refrain from reimposition of controls, and provide income subsidies to the poor, as needed.

- Natural Gas Price Deregulation - Consider new legislative proposals to advance the speed of deregulation, if practicable. Otherwise, in implementing NGPA, residential and comercial customers should more quickly bear the added price burden during the phase-in period. 
- Wholesale Electric Rates Regulation - The Federal Energy Regulatory Commission, in conducting wholesale electric rate-making proceedings, should promote principles of marginal cost pricing.

- Retail Utility Rate Reform - The ERA should be directed to implement PURPA vigorously, and adhere to or advance the timetable set forth in the act. Frequent staff contact with state regulatory authorities should be maintained and marginal cost pricing promoted. Finally, when in the public interest, ERA should actively intervene in individual utility rate-making proceedings.

\subsection{RESEARCH AND DEVELOPMENT}

Research and development (R\&D) activities are an important component of a long-run strategy to increase the supply of energy, promote energy conservation, and achieve reduced dependence on energy imports. R\&D can be separated into three categories: Basic research--research directed toward increasing scientific knowledge and without regard to practical application or commercial objectives; Applied research--research directed toward practical applications of scientific knowledge and possibly having specific commercial objectives; Development--the direct application of research results to the production of specific products or processes. (National Science Board, 1979. p. 178). Each of these areas of endeavor has its proper role within a long-term energy strategy.

The nature of applied research and development allows it to be focused on creating or improving products in well-defined categories. Therefore, it is not surprising to find large numbers of commercial enterprises investing their funds in applied R\&D. On the other hand, basic research of ten improves know ledge in such a way that potential applications are many and varied and are, 
therefore, beneficial to diverse sectors of the economy. Furthermore, the sectors likely to benefit at the time the research is first undertaken are of ten not easily identifiable. Consequently, basic research tends to be funded mostly by government, private foundations and, to a lesser extent, academic institutions. This arrangement between funding sources and type of research is probably consistent with an optimal allocation of R\&D funds.

Government support of R\&D is justifiable to the extent that societal benefits from the R\&D exceed the benefits that could be captured by individuals and firms. By this criterion, government support is easily more justifiable for basic research than for either applied research or development. This is particularly true given that basic research, which has historically been a fertile source of eventual commercial applications, is an area largely ignored by comnercial enterprises (Berg, 1979).

A strong case for government support of applied R\&D can be made, however, if improper signals are being given to the private sector. Elsewhere in this report, we observed that artificially low energy prices have reduced the potential rewards to the private sector from research and development in energy-related areas. As a result, the actual level of applied R\&D has undoubtedly been below some optimal level. Furthermore, since the benefits from applied R\&D are likely to occur sooner than those from basic research undertaken at the same time, and since the energy crisis may turn out to be a short-run problem, prudence may favor emphasizing applied R\&D at the expense of basic research.

In light of the above, government support of applied R\&D is likely to be beneficial if improper price signals continue to be sent to the private sector and, particularly, if energy prices are not decontrolled in the near future. However, it is important to emphasize that this strategy is an inferior substitute for price decontrols. Optimal prices provide the proper signals and allow scarce government research funds to be channeled into basic research. This will allow society's long-run interests to be better served. 
The following policy instruments are identified:

- Government funding of basic research conducted by academic institutions, other non-profit research organizations, and the national laboratories

- Direct grants for applied R\&D to public and private research organizations, commercial enterprises and individuals

- Direct grants or subsidized loans to enable completion of partially developed products and processes, for which energy-saving potential is promising and where lack of funding is a major obstacle to completion

- Offering of bounties on energy-efficient new products and processes. Amount of bounty would depend on unit energy savings and number of units sold.

With the exception of the instrument supporting basic research, the other instruments have serious disadvantages. With the second and third instruments, there is the inherent difficulty of evaluating the potential energy savings and commercial value of undeveloped or partially developed products or processes. Thus, the potential for wasting research funds is considerable. The third instrument is less vulnerable to waste than the second, particularly if subsidized loans are used instead of grants, for the fund recipient has a financial stake in the outcome and a partially developed product can usually be better evaluated than an undeveloped one. The fourth instrument has the major advantage that it rewards performance rather than prospects, but the difficulties in implementing such a policy could prove insurmountable. This instrument is also open-ended and could prove very expensive to the federal Treasury.

A policy that is indirectly related to the stimulation of research and development relates to government-held patents. Existing policy prohibits such patents from being awarded to private firms or individuals, since they result from the expenditure of public funds. Because anyone may use these patents, no one is protected from subsequent competition. As a result, many 
products and processes developed with government funds never make it to the marketplace. A policy whereby exclusive patent rights to these products and processes were auctioned to the highest bidder would have two beneficial results. The government would receive the auction proceeds, which could then be reinvested into additional research, and many of the products and processes would be subsequently marketed or adopted. The monopoly rights conferred by the patent could be restricted to, say, five years if such restriction is deemed desirable. Such a policy for government patents cannot be justified, however, on economic efficiency grounds.

\subsection{INFORMATION, EDUCATION, AND DEMONSTRATION PROGRAMS}

Since inadequate information and its effect on consumer decision-making are among the major barriers to energy conservation, programs designed to provide reliable and credible information to the relevant market participants would be highly beneficial. In this section, four policy instruments to facilitate information dissemination are described. These are the Building Energy Labeling Program, the Technology Transfer Program, the Energy Extension Service, and a mass media campaign.

\subsubsection{Building Energy Labeling Program}

It is possible to require that, at the completion of construction and prior to the occupancy of residential and commercial buildings, the design space-conditioning cost (DSCC) for the first year of occupancy be estimated and provided to a 11 prospective buyers or occupants. The DSCC would be based on current energy costs at the building site and on the assumptions of normal building use and normal weather. Prospective home buyers or occupants could then use the DSCCS to compare the relative thermal efficiencies of (new) buildings, in much the same way that prospective automobile consumers use EPA mileage estimates to compare the fuel efficiencies of new cars.

Th is opportunity to evaluate the trade-off between the building's purchase price or rental and its DSCC provides a firm basis for improved consumer decision-making. Without the DSCC estimate, the consumer cannot be as confident that the energy savings--and lower utility bills--paid for in higher first costs or rentals will in fact be realized. 
Except for the labeling requirements, the Buildings Energy Labeling Program preserves freedom of choice among designers, builders, home buyers and renters. The designers and builders remain free to design and construct homes and commercial buildings in line with their perception of market demand, using whatever materials and equipment they choose within the limits imposed by local codes. The consumer remains free to choose among a variety of buildings, and his decision will depend in part on his assessment of, and preference for, risk and his evaluation of the future. This program would result in minimal intervention in the marketplace, and it is consistent with the philosophy underlying such consumer protection legislation as truth-in-advertising, truth-in-lending, and automobile fuel efficiency estimates.

Another advantage of this approach is that it economizes on information, relative to BEPS: only the actual price of the energy at the building site is needed, instead of the price projections over a 30- or 40-year period that are required for BEPS. The large uncertainties inherent in long-term cost and price projections makes the Building Energy Labeling approach less controversial and easier to implement. Similarly, in contrast to BEPS, the Building Energy Labeling Program does not require using "weighting factors" for oil, natural gas, and electricity; ${ }^{(a)}$ weighting factors are another major area of controversy under BEPS.

The success of the Building Energy Labeling Program depends on the willingness of buyers and renters of new buildings to accept and their ability to utilize the DSCCS; consumer use of EPA mileage estimates in new-car purchasing decisions is encouraging in this regard.

The speed with which energy savings would be realized under the labeling program, as compared with BEPS, should also be considered. The comparison will be more favorable the more quickly and more completely domestic energy prices rise to their optimal levels. A final difficulty, that of computing the DSCC, has been mitigated by the research conducted for the development of BEPS.

(a) As will be discussed in Section 5 and 6, the recommended energy strategy includes imposing a tax on imported energy and energy sources. This tax reflects the adverse effect on national security caused by increased energy dependence on foreign sources. 


\subsubsection{Technology Transfer Program}

In the area of new residential and commercial buildings, there is great potential for transferring technology to practitioners. For example, greater familiarity on the part of architects and builders with performance data for existing and emerging technologies---such as insulation, passive solar and other renewable resource systems, small-scale community energy systems, energy-efficient building designs, and new construction practices--would encourage them to incorporate such techniques in buildings. Several actions are possible:

- Seminars and Workshops - Short seminars would be held at geographically dispersed locations and targeted to specific audiences. Designers and builders could attend workshops covering performance data on materials, designs, and processes. Local code officials could have workshops on code enforcement. Loan officers, realtors, and interested consumers could attend workshops dealing with lifecycle costing, financing arrangements, and tax credits. These workshops and seminars should be coordinated through the Energy Extension Service (discussed below), and with state and local agency personne1.

- Expert Assistance - There may be a need to maintain, on a continuing basis, a pool of experts who are familiar with present and emerging technologies as well as regional and local conditions. These experts could be made available under an Energy Extension Service program.

- Model Building Demonstration - It may be desirable to implement a program to construct model, energy-efficient, residential and commercial buildings. Such a program could be coordinated with private groups such as regional and local home builders' associations and utilities. One possibility would be to build model homes in each county of the nation, so that buyers could have a first-hand look at energy-efficient designs. Design professionals and builders might 
also be influenced by such buildings. Open competitions and awards to designers and builders could be held and publicized to promote public interest.

\subsubsection{Energy Extension Service (EES)}

Expansion of the Energy Extension Service from the ten-state pilot program to all fifty states is currently underway. Emphasis should be placed upon the Service's potential to provide relevant information and assistance to architects, builders, local code officials, realtors, loan officers, and new home buyers at the grass roots level. EES personnel could participate in and coordinate the workshops/seminars and the building energy labeling and technology transfer programs. The EES could also become the focal point for the pool of local building-energy experts. Maintained at the local or regional level within each state, information provided by EES to consumers and others could achieve a high level of credibility. It is suggested that EES programs be closely monitored and evaluated on a continuing basis.

\subsubsection{Mass Media Campaign}

A mass media compaign could be aimed at two levels. One would be to raise the general consciousness and awareness of energy problems and to induce a positive attitude toward energy conservation and use of renewable resources. The other would be to highlight specific aspects of various programs, such as the Building Energy Labeling Program, the energy-efficient home design and construction workshops, the energy-efficient model home program, etc.

\subsubsection{Summary}

This section discusses four options aimed at informing and educating the participants in the market for new buildings. It should be noted that the technology transfer programs, the EES, and the mass media campaign are ongoing programs for which some adjustment in emphasis is suggested. They can be continued with or without mandatory BEPS. In contrast, the Building Energy Labeling Program would be a real alternative to mandatory BEPS. Compared to BEPS, this program would allow maximum freedom of choice to designers, builders, building buyers and renters to act according to their individual 
preferences and the price signals provided by the market. It would avoid the difficulties and controversy in projecting long-term future prices of oil, natural gas, and electricity, as we 11 as those associated with weighting factors. On the other hand, the Building Energy Labeling Program's contribution to short-term and intermediate-term conservation goals needs to be further investigated.

\subsection{TAX INCENTIVES/DISINCENTIVES}

The tax system can be utilized to promote conservation and use of renewable resources in new buildings by subsidizing investment in such activities and by taxing activities which are wasteful of energy resources. Five options suggest themselves:

(a) tax credits for investing in conservation and renewable resource systems;

(b) accelerated amortization of investments in conservation and renewable resources in new residential housing units;

(c) tax on energy-inefficient buildings;

(d) tax on fuels and electricity consumption; and

(e) tax on imported fuels and energy products.

Some of these options are already incorporated into the present tax system. For example, the Energy Tax Act of 1978 allows tax credits of 15 percent of certain conservation investments, up to $\$ 2000$ on existing buildings (i.e., a maximum credit of $\$ 300$ ) for the period 1977-1985. It also provides for a tax credit up to $\$ 2200$ for investment in renewable resources in existing as we 11 as new buildings. (Office of Technology Assessment, 1979. p. VIII 38-39). It may be desirable to expand these credits.

If tax credits, under option (a), and accelerated amortization of investment, under option (b), are to be restricted to new, energy-efficient buildings, the problem of obtaining a satisfactory working definition of "energyefficient building" must be solved. The same problem is encountered in option (c), taxing energy-inefficient buildings. On the other hand, both 
option (d), which taxes energy consumption, and option (e), which taxes only imported fuel and energy products, avoid this difficulty. Furthermore, options (a) and (b) make special demands on the taxpayer: he must complete and file a special tax form to receive the tax benefit. While options (c) and (d) would also involve filing requirements, they would more likely impact firms rather than individuals, and their overall administrative impact would, therefore, likely be less severe.

The practical effects of options (a) and (b) are to lower the effective initial cost of energy-efficient buildings, relative to the inefficient ones. Option ( $c$ ), on the other hand, raises the initial cost of purchasing energyinefficient buildings. A variation that combines the effects of (a) and (c) is a sliding-scale charge on new connections for natural gas and electricity hookups, with the charge depending on the energy conserving features of the new building. The California Public Utilities Commission recently adopted rules for such a plan. "The new rates will offer builders allowances and incentives for including such items as energy-efficient appliances, solarassisted heating systems, extra insulation and locating the house for maximum exposure to the winter sun. Each energy-saving item will be assigned points, which will be converted by formula into dollars" (San Jose Mercury, 1980 and California Public Utilities Commission, 1980, pp. 189-190). Under California's plan, energy-inefficient homes could be charged up to $\$ 2000$ more for the hookup. A charge that varies according to the length of extension to the existing utility lines would also tend to increase the density of housing and, therefore, it would have implications for energy conservation in transportation. A major disadvantage with the California plan is that it introduces market distortions between old, energy-inefficient homes, which are not taxed, and new homes, which are taxed but are likely to be more energy-efficient than older homes. Thus, while newly constructed homes will tend to be more efficient as a result of the tax, fewer new homes will be constructed and the attrition rate for older, energy-inefficient homes will be reduced.

The justification for tax benefits or penalties on economic efficiency grounds lies in their potential to offset the market distortions created by 
externalities; that is, social costs would be taxed and social benefits would be subsidized to the extent that they are not accounted for by market transactions. Another possible justification is to speed up the adjustment process from one equilibrium to another, given a change in supply or demand conditions. This latter justification may be weak, however, because accelerating a (sma11) part of the adjusting economy causes both intra- and inter-temporal distortions, at least in the short run. The California plan exemplifies this weakness.

In light of the above discussion, it would appear that the first three options run a greater risk of adversely affecting economic efficiency than the last two options. Option (d), the tax on energy consumption, is justifiable as an alternative to decontrolled energy prices. The size of the tax, in this case, would equal the difference between the controlled price and the optimal price for each controlled energy resource. With such a tax, energy consumers would face--and react to--the same prices that would occur under decontrol, assuming no external energy effects. Decontrolled prices, however, have a more beneficial effect on the supply side, since the increased potential rewards to energy producers would give rise to increased supplies of domestically produced energy; domestic supply is decreased by a tax.

Option (e), which would impose a tax only on imported energy and energy products, may be justifiable on national security grounds. Current national policy attaches a premium to reduced dependency on energy imports. Attaching a penalty $(\operatorname{tax})$ to domestic use of foreign $0 i 1$, for example, is consistent with this policy. (In the absence of energy price decontrols, options (d) and (e) could be applied in tandem by making the tax higher on imported energy and energy products.)

Higher energy costs to consumers may impose a socially unacceptable financial burden on lower-income households. Where these higher costs are the result of taxes on energy, the tax proceeds can be used to offset these burdens. It should be added, however, that these subsidies should be in the form of income supplements and/or reduction in the cost of energy conservation. Using the subsidy to reduce the price of energy to the poor encourages energy consumption by them and, therefore, should be avoided. 


\subsection{MORTGAGE FINANCE PROGRAMS}

The more energy-efficient a new building, the higher are its first cost and monthly payments likely to be, other things remaining equal. Since most new buildings are financed, mortgage/finance programs constitute another set of policy instruments for promoting energy conservation and use of renewable resources in new buildings. The major objective of these is to reduce the disadvantage of higher initial costs and monthly payments attributable to energy-efficient buildings. Possible instruments include:

(a) creation of a solar and conservation bank to provide subsidies for investments in conservation, solar and other renewable resources;

(b) inclusion of expected utility costs in calculating expense-to-income ratios when evaluating loan applications;

(c) requiring lower down payments for energy-efficient homes;

(d) providing a direct interest rate subsidy to buyers of energyefficient buildings; and

(e) giving preference to energy-efficient buildings in approving FHA/VA loan applications.

The creation of a solar bank has been proposed as a way to reduce the first-cost of housing to consumers who buy new homes with solar features. Such a bank could also subsidize conservation features other than solar. In effect, such a bank subsidizes solar energy at the expense of other types of 
energy, and it benefits those receiving subsidizes at the expense of others. on economic efficiency grounds, such a subsidy is difficult to justify(a)(b).

In evaluating a prospective home buyer's mortgage application, financial institutions have traditionally ignored the impact of a building's conservation features on the occupant's utility bills. In the past, this practice could be defended because such bills represented a relatively minor item in the household's budget. With today's energy prices, however, the size of a homeowner's utility bill can significantly affect his ability to meet his mortgage obligation. Nevertheless, lending institutions have been slow to include expected utility bills in expense-to-income ratios used in evaluating an applicant's credit-worthiness. The effect of ignoring expected utility bills is to penalize buyers of energy-efficient housing. Policies to redress this imbalance may be socially desirable. However, possible implementation difficulties should be considered. Requiring lending institutions to include expected utility bills in evaluating credit-worthiness may be unenforceable, since such evaluations inherently involve judgments apart from those relating

(a) The distinction between renewable and nonrenewable, or depletable and nondepletable, resources tends to obscure rather than elucidate the relevant issues pertaining to the supply of energy. The renewable/ nonrenewable resource issue is really one of long-run supply conditions. To illustrate this, we note that, in exploiting oil fields, operations are often abandoned after only two-thirds or less of the $0 i 1$ in the field has been extracted. The reason for this is simply that the marginal cost of extracting the remainder of the oil exceeds the price (marginal revenue) that could be obtained for it. Thus, $0 i 1$ is in fact nondepletable--in the sense that higher prices will always elicit additional supplies--even though the cost of extracting additional supplies may be sharply increasing. The supply of other energy forms, such as solar or geothermal, also is subject to increasing supply costs, since the least costly opportunities will tend to be exploited first.

Now it may we 11 be that in the near future a given price increase for energy will cause a greater increase in the supply of solar energy than of fossil energy; but this does not justify subsidizing solar or penalizing fossil. Total energy use will be most efficient when a 11 lower-cost energy sources are exploited before any higher-cost sources are exploited. The subsidizing of one energy source and/or taxing of another energy source causes this principle to be violated.

(b) On June 30, 1980, President Carter signed the Energy Security Act (PL 96-294). Title $V$ of the Act establishes a Solar Energy and Energy Conservation Bank. 
to utility bills. Requiring lower down payments (option (c)), interest rate subsidies (option (d)), or FHA/VA preferential treatment (option (e)) for energy-efficient homes a 11 require an operationally useful definition of "energy efficiency."

\subsection{REGULATION AND STANDARDS}

At the opposite end of the scale from greater reliance on the marketplace is the category of regulation and standards. Three options are discussed below: Building Energy Performance Standards (BEPS), as mandated by Congress; prescriptive standards (including a ban on specific types of equipment), and fue 1 rationing/curtailment.

\subsubsection{Building Energy Performance Standards (BEPS)}

BEPS was mandated by the Energy Conservation and Production Act (ECPA) of 1976. As proposed by DOE (44 FR 68120, November 28, 1979) the standards would:

- Establish Energy Budget Levels by building type and by climatic region. For single-family homes, Energy Budget Levels are set at the minimum life-cycle cost point (LCC minimum);

- Provide a mechanism for deriving the Design Energy Budget of a specific building design from the Energy Budget Levels;

- Specify methods for calculating Design Energy Consumption for individual building designs;

- Require that the Design Energy Consumption not exceed the Design Energy Budget.

BEPS sets a performance requirement for the whole building without prescribing the requirements for the component parts of the building. Thus, it allows the designer of a building to take advantage of various technologies, local conditions, and individual preferences in making the trade-offs among various building components, alternative design strategies, materials, and processes. It also fosters the use of renewable resources by excluding the 
energy supplied by solar systems from the calculation of Design Energy Consumption. However, BEPS can also be implemented via a prescriptive components path.

BEPS can be implemented with or without sanctions and incentives. ECPA provides that "no federal financial assistance shall be made available for the construction of any new commercial or residential building in any area of any state" unless that area takes appropriate action to implement the Standards (Section 305(2)). However, if either House of Congress fails to concur within 90 days of adoption of BEPS, this sanction will not go into effect. ECPA also authorizes HUD to make grants as well as provide technical assistance to state and local governments to aid them in implementing BEPS (Sections 307 and 308). In addition, Section 252 of National Energy Conservation Policy Act (NECPA; P.L.95-619) requires that the Minimum Property Standards (MPS) of the Federal Housing Administration (FHA) and the Farmers Home Administration (FmHA) shall be revised to conform with BEPS when the latter becomes effective. Section 546 of NECPA further requires any new federal building construction to be in compliance with the Standards.

Possible ways of implementing BEPS include no sanction/no incentives (no action), incentives/no sanction, incentives/sanctions, and no incentives/ sanctions. In terms of probable impacts on the penetration rates of new construction in compliance with the standards, the no sanction/no incentives option and the sanction/incentive option, respectively, represent the least and the most effective (in terms of penetration, but not necessarily in terms of cost-effectiveness) implementation options. Therefore, on ly these two options are summarized here (DOE 1980a, pp. 3.1-3.55). We note that the following results are based on analyses conducted in 1979 . More recent information has since become available and is currently being used to reevaluate the impacts of BEPS. Some of the results reported below may, therefore, be revised in the near future.

\subsubsection{No Sanction/No Incentives}

Beyond the development and promulgation of the Standards, this option requires only (a) the revision of the MPS of FHA and FmHA to meet the standards, (b) monitoring and reporting, and (c) compliance of new federal 
buildings. No other specific implementation action would be taken. In 1976, approximately $15 \%$ of new residential and $6 \%$ of commercial buildings were federally insured, financed, and/or secured. These percentages, then, represent the low end of the possible range of penetration of BEPS buildings in total new construction. In addition, it is likely that some new construction will be in voluntary compliance with the Standards. The upper limits of penetration rates for BEPS buildings are estimated to be $50 \%$ for residential and $30 \%$ for commercial buildings in 1982. By 1990, these penetration rates are projected to rise to $57.4 \%$ and $46.2 \%$. In the year 2000 , the higher end of the range of penetration rates under this option is projected to be approximately $67 \%$ for both residential and commercial buildings.

The costs of this option are estimated to be $\$ 1.3$ million(a) (one-time) for implementation and $\$ 0.25$ million for annual administration to the federal government. In addition, the cumulative implementation and enforcement costs to all levels of government (federal, state and local) are in the range of \$50-160 million for the period 1980-2000 (DOE 1980a, p. 3.15).

Since the initial cost of BEPS buildings would be higher than otherwise and since no incentives are provided, prospective new home buyers under FHA and FmHA financing programs would face larger first costs. Politically, BEPS implemented under this alternative could be viewed by some as a half-hearted response to the requirements of ECPA. On the other hand, this option would minimize government interference in the marketplace, making it relatively attractive to others.

\subsubsection{Sanctions/Incentives}

This option would require major federal, state and local efforts, in addition to the minimal activities described in the No Sanctions/No Incentives approach. The appropriate agencies would be required to:

- Develop and administer programs for state certification, alternate approval processes and exemptions.

(a) All cost estimates cited are in terms of constant 1978 dollars. 
- Institute programs for public information, technical assistance and demonstration projects.

- Promulgate and implement rules for market incentives and grants.

- Review state and local compliance with the Standards and apply sanctions.

Under this option, penetration rates of buildings meeting BEPS are estimated to reach $60-67 \%$ for residential homes and $43-67 \%$ for commercial buildings in 1982. These rates are estimated to rise to $78-94 \%$ (residential) and $70-94 \%$ (commercial) in 1990, and $90-100 \%$ (residential) and $83-100 \%$ (commercial) in the year 2000 .

The costs of implementing and administering this option are estimated to approximate $\$ 11.15 \mathrm{million}$ (one-time implementation cost) and $\$ 1.05 \mathrm{million}$ (annual administrative cost) to the federal government. The cumulative costs to 211 governments are estimated at $\$ 310-\$ 380$ million for the $1980-2000$ period (DOE 1980a, p. 3.16).

Incentives and sanctions would be structured and targeted to achieve the desired level of compliance. For example, incentives would be concentrated in states and localities with high rates of new construction. However, such targeting could result in perceived and actual inequity among states.

\subsubsection{Full Compliance Impacts}

If we assume $100 \%$ compliance for residential single-family housing and 80\% compliance for commercial and multiple-family buildings by 1982 and thereafter, the economic impacts of BEPS would be as follows (DOE 1979b):

- Energy Savings - Under BEPS, energy requirements of individual new residential buildings would be reduced by $17-52 \%$ from $1975-76$ levels. Similarly, compliance with BEPS might save between $30 \%$ to $45 \%$ of energy consumed in individual commercial buildings. Savings are projected to amount to 0.22 quad $(0.1 \mathrm{million}$ barrels per day of oil equivalent, MBDOE) by 1985, and 0.46 quads annually (0.2 MBDOE) by 1990 . Cumulatively, savings 
between 1980 and 2020 wi11 amount to 20 quads, with approximately $40 \%$ of this savings from residential buildings and $60 \%$ from commercial buildings.

- Net Present Values - In constant 1978 dollars and evaluated at (average) prices projected by EIA (4/30/79), the estimated present value of the energy savings amounts to $\$ 6$ billion, slightly less than half of which is from the residential sector and the rest from the commercial sector. The present value of energy savings would be higher if the marginal costs of energy are used.

- First Cost of New Buildings - Increases in the first cost of new buildings are estimated to be about $2 \%$, or between $\$ 900$ and $\$ 1300$ (in constant 1978 do 11 ars) for single-family, detached homes, and about 2 percent for commercial buildings.

- Employment - With BEPS, employment is projected to rise by 48,000 in 1980 , by 86,000 in 1985 , and by 70,000 in 1990 , as compared to no-BEPS.

- GNP - The impact of BEPS on GNP is positive but relatively small, less than one-tenth of $1 \%$.

- Inflation - There would be a small, adverse effect on inflation in the initial years of implementing BEPS. In later years, energy prices would be lower than without BEPS, thus offsetting the higher initial cost of new buildings.

- Competition - Overall, no significant impact on the competitive structure of the economy is expected.

\subsubsection{Prescriptive Standards Only}

This option would establish minimum standards for various building construction components including materials, processes, and construction practices. Insulation levels, window glazing, levels of heating, ventilating, and air conditioning equipment efficiency, and lighting levels could all be 
specified. Some types of equipment, materials, or processes might be prohibited. For example, there have been proposals for banning the use of baseboard electric resistance heaters.

Most existing building codes as well as the HUD-MPS are prescriptive. Therefore, the main advantage of this option would be its ease of implementation (Graves and Fletcher 1980). Theoretically, it is possible to set prescriptive standards so as to achieve the same level of energy savings as BEPS. However, this could prove very restrictive because the flexibility under BEPS would be lost. Prescriptive standards tend to discourage research, development, and adoption of more energy-efficient equipment, materials, designs, and processes. As a result, the initial cost of new buildings under this option would likely be higher than under BEPS, even though design costs would be lower.

\subsection{Fuel Rationing/Curtailment}

The rationing/curtailment option would operate similarly to the gasoline rationing plan, and could be applied to heating oil. For electricity and natural gas, it would be more appropriately applied in emergency situations such as massive outage of generation plants, transmission and distribution networks, and for peak shedding. Moratoria on electricity and natural gas hookups have been used occasionally in the past. This option should be regarded only as an emergency option in allocating a limited supply of energy among high-priority users. Otherwise, it is a very inefficient, restrictive method for promoting energy conservation and use of renewable resources.

\subsubsection{Summary}

This section considers three options in regulation and standards for promoting energy conservation in new buildings: building energy performance standards (BEPS) prescriptive standards, and fuel rationing/curtailment. As proposed by DOE, BEPS is flexible and allows freedom of choice within the limits imposed by the Design Energy Budget, which is set to promote maximum practicable conservation and use of renewable resources. BEPS can be promulgated and implemented in different ways and at more or less stringent levels. (See DOE 1979b, c, d, and 1980a for details.) BEPS, as proposed, can 
be implemented with no further federal action (no incentives/no sanctions)except for the necessary changes in HUD-MPS and federal buildingsor with a ful1 complement of incentives and sanctions, or a mixture of both. Since BEPS provides for prescriptive alternatives, it is less restrictive than a policy requiring prescriptive standards. In terms of economic efficiency, it is superior to either the prescriptive or rationing/curtailment option. 


\section{COMPARATIVE ANALYSIS OF FIVE ALTERNATIVE STRATEGIES}

The various policy instruments explained in the previous section can be combined in many different ways to design a strategy for promoting conservation and the use of renewable sources of energy in new buildings. These instruments can be regrouped into four categories: (1) those that complement nearly any strategy and approximately to the same extent; (2) those that complement nearly any strategy, but whose effectiveness or importance depends upon the particular strategy; (3) those that may more properly be viewed as major policy alternatives; and (4) other policy instruments. All five of the strategies described below will contain the policy instruments in the first two categories. These policy instruments are: (Category 1) - federal support of basic research; (Category 2) - Building Energy Labeling Program, Technology Transfer Program, expansion of the Energy Extension Service, mass media campaigns, tax on imported energy and energy products, inclusion of expected utility costs in calculating expense-to-income ratios when evaluating loan applications, federal law enabling designers and builders to satisfy state and local energy codes via a performance equivalency path, and income subsidies to protect low-income households from increased energy costs.

The policy instruments in Category (3)--those that can be viewed as major policy alternatives--are greater reliance on the marketplace via energy price decontrols, a tax on energy consumption, and new building energy performance standards. These form the basis for the five energy strategies analyzed in th is section.

\subsection{FIVE STRATEGIES}

The five strategies for promoting the optimal level of energy conservation are sumarized below. In addition to the policy instruments identified under each, they all contain the Category (1) and (2) instruments identified above. 
Strategy A (Increased Reliance on the Marketplace)

- Continue the current timetable for oil price decontrol and natural gas deregulation, and implement utility rate reform as set forth under the Public Utility Regulatory Policy Act (PURPA).

Strategy B (Energy Consumption Tax and Supply Subsidies)

- Maintain price controls on oil and natural gas.

- Do not implement PURPA.

- Impose a consumption tax on fuels and electricity consumption. The tax would be sufficiently large so that consumers would face the same energy prices that they would in a perfectly competitive market.

- Increased subsidies for conservation and renewable sources of energy.

- Federal grants and subsidized loans in support of applied R\&D.

- Federal grants and subsidized loans to enable completion of partially developed products and processes.

Strategy C (BEPS with No Sanctions and No Incentives)

- Continue the current timetable for oil price decontrol and natural gas deregulation, and implement utility rate reform via PURPA.

- Promulgation and implementation of BEPS, but without sanctions or incentives.

Strategy D (BEPS with Sanctions and Incentives; Price Controls)

- Maintain price controls on $0 i 1$ and natural gas.

- Do not implement PURPA.

- BEPS are promulgated and implemented with sanctions and incentives. The sanctions include (a) denial of federal grants to state and local governments, (b) denial of federal financial 
assistance for construction of new commercial and residential buildings, and (c) blacklisting state and local governments not in compliance with the Standards. The incentives would include tax credits, grants, and technical assistance.

Strategy E (BEPS with Sanctions and Incentives; No Price Controls)

- Continue the current timetable for oil price decontrol and natural gas deregulation, and implement utility rate reform via PURPA.

- BEPS are promulgated and implemented with sanctions and incentives, as in Strategy $D$.

To capture major ingredients of the individual strategies and to facilitate exposition, the increased reliance on the marketplace, Strategy (A), is also referred to as the Market Strategy; the Energy Consumption Tax and Supply Subsidies (B), the Tax and Subsidy Strategy; BEPS with No Sanctions and No Incentives (C), Simple BEPS; BEPS with Sanctions and Incentives, as we 11 as Price Controls (D), Full BEPS; BEPS with Sanctions and Incentives but No Price Controls (E), Medium BEPS.

\subsection{COMPARATIVE ANALYSIS OF THE ALTERNATIVE STRATEGIES}

In comparing the five alternatives, it is important to remember that all five contain the Category (1) and (2) policy instruments. In particular, the information and education programs play an important role in Strategies $A$ and $C$, whose success depends, in large measure, on consumers being we11-informed. The other three strategies also significantly benefit from these programs, for they are important in reducing public resistance to the strategies and in fostering public cooperation. Furthermore, the required information has already been largely developed in the course of conducting the research for BEPS. Making the information available to the public should, therefore, be relatively inexpensive.

The tax on imported energy sources and energy products is necessary to all strategies to the extent that there is a social cost attached to increased 
national dependence on imported energy; none of the strategies otherwise treat this social cost. The policy instrument requiring inclusion of expected utility costs in mortgage loan applications is essential to none of the strategies, but, provided that it could be implemented in a reasonable and effective way, it would enhance each of them.

A federal law enabling designers and builders to satisfy state and local energy codes via a performance equivalency path is seen as an effective way to overcome the disincentives to energy conservation inherent in most state and local energy codes. It should be pointed out that under BEPS the performance path (with prescriptive equivalents) would already be available.

Finally, income subsidies to low-income households are provided under all of the strategies. The total amount of these subsidies would be greater if energy prices are decontrolled, but energy conservation would also be greater because all uses of energy would become more expensive, and not just the energy used in (new) buildings.

In what follows, the five strategies are evaluated in terms of the criteria established in Section 2. These are: (1) energy conservation; (2) economic efficiency (distributive, productive and inter-temporal), including the effect of the strategy on market competition, externalities and speed of adjustment; (3) equity, including income and wealth distribution and unemployment; (4) political obstacles; (5) implementation obstacles; and (6) other transitional effects. In following the discussion below, it is useful to refer to Table $A$.

\subsection{Energy Conservation}

In Section 3 we defined an optimal level of energy conservation. The following evaluation of the level of energy conservation offered by the five strategies is in terms of this optimal level.

The most effective policy instrument for approaching an optimal level of energy conservation for all types of energy is price decontrol of $0 i 1$ and natural gas and utility rate reform, as set out in PURPA. Strategies $A$ (The Market Strategy), C (Simple BEPS), and E (Medium BEPS) all contain this policy instrument. 
TABLE A. Comparison of Alternative Strategies for Promoting Energy Conservation and Use of Renewable Resources in New Buildings

\begin{tabular}{|c|c|c|c|c|c|}
\hline $\begin{array}{l}\text { Strategy } \\
\text { Components } \\
\text { Criteria }\end{array}$ & $\begin{array}{c}\text { A } \\
\text { Increased } \\
\text { Reliance on } \\
\text { Harketplace } \\
\end{array}$ & $\begin{array}{c}8 \\
\text { Energy Consuant ion } \\
\text { Tax and } \\
\text { Supply Subsidies } \\
\end{array}$ & $\begin{array}{l}\text { C } \\
\text { BLPS - No Sanctions/ } \\
\text { No Incentives and } \\
\text { No Price Controls } \\
\end{array}$ & $\begin{array}{l}D \\
\text { BEPS - Sanctions/ } \\
\text { Incentives and } \\
\text { Price Controls } \\
\end{array}$ & $\begin{array}{l}\text { E } \\
\text { BEPS - Santions/ } \\
\text { Incentives and } \\
\text { No Price Controls } \\
\end{array}$ \\
\hline $\begin{array}{l}\text { Strategy } \\
\text { Comporients }\end{array}$ & $\begin{array}{l}\text { - Adhere to current schedule } \\
\text { of decontrolling oil ani } \\
\text { gas prices. } \\
\text { - lawienent utility rate } \\
\text { reform (PURPA). }\end{array}$ & $\begin{array}{l}\text { - Impase consuuntion } \\
\text { tax on fuels and } \\
\text { electricity. } \\
\text { - Mainta in price con- } \\
\text { trols on oil and } \\
\text { natural gas. } \\
\text { - Do not inpleillent } \\
\text { PURPA. } \\
\text { - Increase subsidies } \\
\text { for conservation } \\
\text { and renewable } \\
\text { resource use. } \\
\text { - Federal grants and } \\
\text { loans for applied } \\
\text { R8D. } \\
\text { - Federal grants and } \\
\text { and loans for com- } \\
\text { plet ing energy pro- } \\
\text { ducts and processes. }\end{array}$ & $\begin{array}{l}\text { - Promulgate and } \\
\text { implentent BEPS without } \\
\text { sanctions or incen- } \\
\text { tives. } \\
\text { - Adhere to current } \\
\text { schedule of decontrol- } \\
\text { ling oil and gas } \\
\text { prices. } \\
\text { - limplement ut jlity } \\
\text { rate reform (PURPA). }\end{array}$ & $\begin{array}{l}\text { - Promulgate and imple- } \\
\text { llent BEPS with sanc- } \\
\text { tions and incentives. } \\
\text { - Maintain price controls } \\
\text { on ofl and natural gas. } \\
\text { - Do not implement PURPA. }\end{array}$ & $\begin{array}{l}\text { - Promulgate and imple- } \\
\text { ment oEPS with } \\
\text { sanctions and incen- } \\
\text { tives. } \\
\text { - Adhere to current } \\
\text { schedule of decontrol- } \\
\text { ling oil and gas prices } \\
\text { - lmpleutent utility } \\
\text { rate reform (PURPA). }\end{array}$ \\
\hline
\end{tabular}


TABLE A. (Contd)

\begin{tabular}{|c|c|c|c|c|c|}
\hline $\begin{array}{l}\text { Strategy } \\
\text { Coniponents and } \\
\text { Criteria }\end{array}$ & $\begin{array}{c}\text { A } \\
\text { Increased } \\
\text { Reliance on } \\
\text { Marketplace } \\
\end{array}$ & $\begin{array}{c}B \\
\text { Energy Consumption } \\
\text { Tax and } \\
\text { Supply Subsidies } \\
\end{array}$ & $\begin{array}{l}\text { C } \\
\text { BEPS - No Sanctions/ } \\
\text { No Incent Ives and } \\
\text { No Price Controls } \\
\end{array}$ & $\begin{array}{l}\text { D } \\
\text { BEPS - Sanctions/ } \\
\text { Incent ives and } \\
\text { Price Controls } \\
\end{array}$ & $\begin{array}{l}\text { EEPS - Santions/ } \\
\text { Incentives and } \\
\text { No Price Controls } \\
\end{array}$ \\
\hline $\begin{array}{l}\text { I1. Energy } \\
\text { Conservation }\end{array}$ & $\begin{array}{l}\text { - Probably close to optimal, } \\
\text { but level depends on how } \\
\text { well and to what extent } \\
\text { consuners use accurate } \\
\text { information. } \\
\text { - High level of economic } \\
\text { act ivity results in } \\
\text { greater energy consump- } \\
\text { tion. } \\
\text { - Large number of energy- } \\
\text { saving technologies are } \\
\text { developed }\end{array}$ & $\begin{array}{l}\text { - Low level of econo- } \\
\text { mic activity causes } \\
\text { low level of energy } \\
\text { consumption. } \\
\text { - High taxes reduce } \\
\text { total energy con- } \\
\text { sumption. } \\
\text { - Fewer energy-saving } \\
\text { technologies are } \\
\text { developed. }\end{array}$ & $\begin{array}{l}\text { Energy consumption } \\
\text { levels sinilar to } \\
\text { Strategy A. } \\
\text { - High level of economic } \\
\text { activity results in } \\
\text { greater energy consump- } \\
\text { tion. } \\
\text { - Large number of energy- } \\
\text { saving technologies } \\
\text { are developed. }\end{array}$ & $\begin{array}{l}\text { - Low level of econonic } \\
\text { activity causes low } \\
\text { level of energy con- } \\
\text { sumption. } \\
\text { - Proximity to optimal } \\
\text { level depends on } \\
\text { strictness of standards. } \\
\text { Could be either too } \\
\text { much or too little } \\
\text { conservation. } \\
\text { - Fewer energy-saving } \\
\text { technologies are } \\
\text { developed. }\end{array}$ & $\begin{array}{l}\text { - Proximity to optimal } \\
\text { level depends on } \\
\text { strictness of stan- } \\
\text { dards. Could be } \\
\text { either too much or } \\
\text { too little conserva- } \\
\text { tion. } \\
\text { High level of economic } \\
\text { activity results in } \\
\text { greater energy consump- } \\
\text { tion. } \\
\text { - Large number of energy- } \\
\text { saving technologies are } \\
\text { developed. }\end{array}$ \\
\hline $\begin{array}{l}\text { Distributive } \\
\text { Efficiency }\end{array}$ & $\begin{array}{l}\text { - Most efficient anong } \\
\text { five alternatives. }\end{array}$ & $\begin{array}{l}\text { - Moderately efficient, } \\
\text { but supply-side } \\
\text { subsidies distort } \\
\text { allocation. }\end{array}$ & $\begin{array}{l}\text { - Very efficient, but } \\
\text { manda tory application } \\
\text { to FHA/VA homes causes } \\
\text { some misallocations. }\end{array}$ & $\begin{array}{l}\text { - Least efficient - } \\
\text { restricted choices } \\
\text { leave many consumers } \\
\text { worse off, especially } \\
\text { when facing low energy } \\
\text { prices. }\end{array}$ & $\begin{array}{l}\text { - Somewhat more } \\
\text { efficient than } D \text {, } \\
\text { but many consumers } \\
\text { still worse off. }\end{array}$ \\
\hline $\begin{array}{l}\text { Productive } \\
\text { Efficiency }\end{array}$ & $\begin{array}{l}\text { - Most efficient among } \\
\text { five alternatives. }\end{array}$ & $\begin{array}{l}\text { - Very inefficient } \\
\text { usual distortions } \\
\text { from price controls. } \\
\text { - Supply-side subsi- } \\
\text { dies greatly inade- } \\
\text { quate. Ho subsidies } \\
\text { to encourage more } \\
\text { donestic oil and } \\
\text { natural gas. }\end{array}$ & $\begin{array}{l}\text { - Very efficient, but } \\
\text { mandatory appl ication } \\
\text { to FHA/VA homes } \\
\text { causes sone productive } \\
\text { misallocations. }\end{array}$ & $\begin{array}{l}\text { - Least efficient - } \\
\text { usual distortions from } \\
\text { price controls } \\
\text { - However, level of build } \\
\text { ing conservation much } \\
\text { better than with price } \\
\text { controls and no BEPS. }\end{array}$ & $\begin{array}{l}\text { Very efficient - } \\
\text { manda tory standards } \\
\text { reduce value of } \\
\text { total nat ional } \\
\text { output by forcing } \\
\text { resources into } \\
\text { building conserva- } \\
\text { tion. }\end{array}$ \\
\hline
\end{tabular}


IABLE A. (Contd)

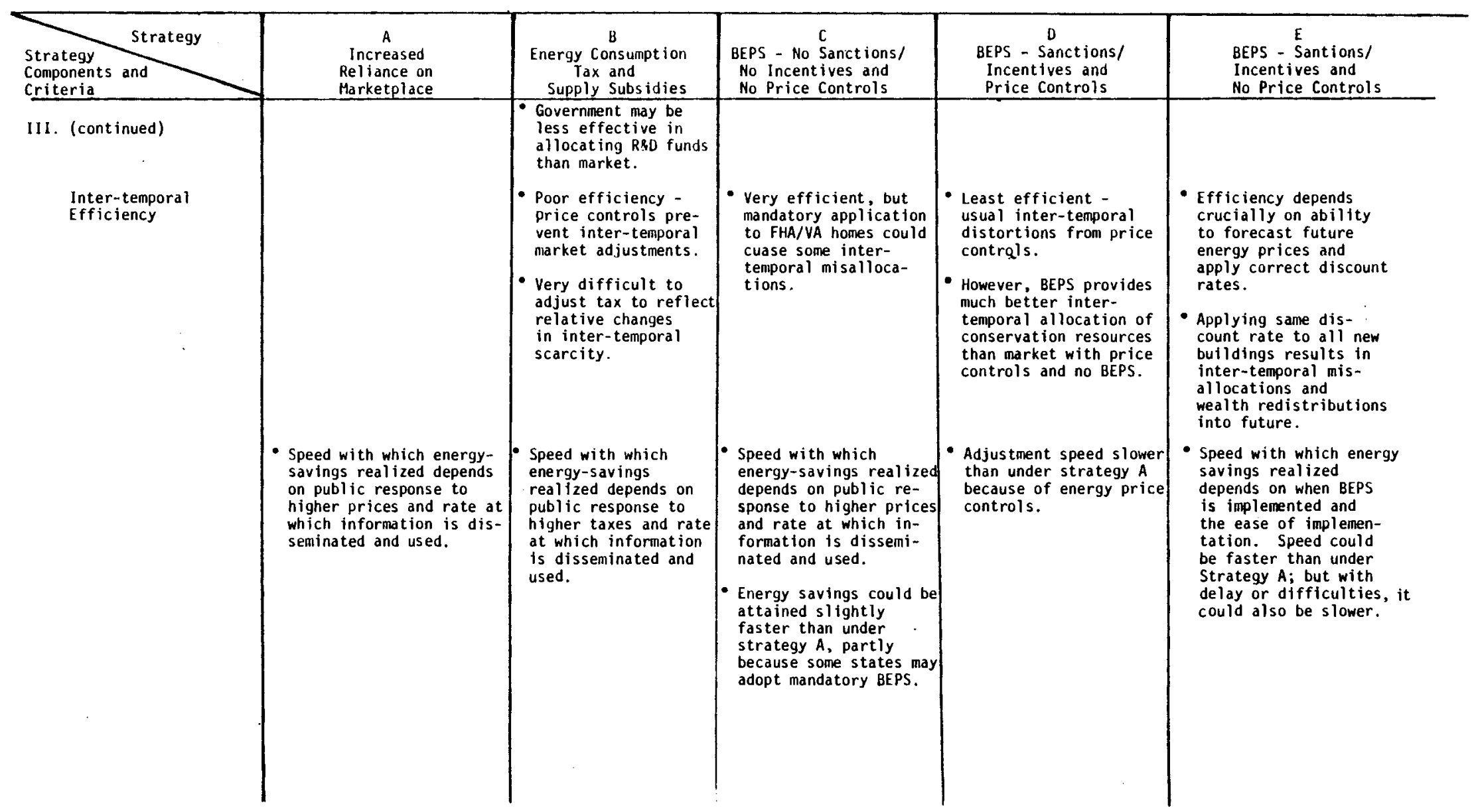


TABLE A. (Contd)

\begin{tabular}{|c|c|c|c|c|c|}
\hline $\begin{array}{l}\text { Stroteyy } \\
\text { Components and } \\
\text { Criteria }\end{array}$ & $\begin{array}{c}\text { A } \\
\text { lincreused } \\
\text { Reliance on } \\
\text { Marketpluce } \\
\end{array}$ & $\begin{array}{c}\text { B } \\
\text { Energy Cunsumption } \\
\text { Tax and } \\
\text { Supply Sulsidies }\end{array}$ & $\begin{array}{l}\text { BEPS - No Sanct ions/ } \\
\text { No Incent ives and } \\
\text { No Pice Controls } \\
\end{array}$ & $\begin{array}{l}\text { DEPS - Sanctions/ } \\
\text { Incent ives and } \\
\text { Price Controls } \\
\end{array}$ & $\begin{array}{l}\text { EEPS - Santions/ } \\
\text { Incentives and } \\
\text { No Price Controls }\end{array}$ \\
\hline \multicolumn{6}{|l|}{ III. (continued) } \\
\hline $\begin{array}{l}\text { Impacts on } \\
\text { Market Conpetition }\end{array}$ & $\begin{array}{l}\text { - Highest level of } \\
\text { competition. }\end{array}$ & $\begin{array}{l}\text { - Reduced level of } \\
\text { compet it ion aunong } \\
\text { energy suppliers. }\end{array}$ & $\begin{array}{l}\text { - Level of competition } \\
\text { alwost as high as } \\
\text { under strategy } A \text {. }\end{array}$ & $\begin{array}{l}\text { - Greatest adverse ia- } \\
\text { pact on competition. } \\
\text { - Reduced level of con- } \\
\text { petition anong } \\
\text { energy suppliers. } \\
\text { - Increased regulations } \\
\text { and restriction's keep } \\
\text { many small suppliers } \\
\text { out of market. } \\
\text { - Market power exercised } \\
\text { by some suppliers of } \\
\text { bullding materials. }\end{array}$ & $\begin{array}{l}\text { - Some adverse finpacts } \\
\text { on competition. } \\
\text { - Increased regulations } \\
\text { and restrictions keep } \\
\text { many sniall suppliers } \\
\text { out of market. } \\
\text { - Market power exercised } \\
\text { by some suppliers of } \\
\text { bulld ing materials. }\end{array}$ \\
\hline Externdlities & $\begin{array}{l}\text { - Tax on imported energy } \\
\text { sources and energy pro- } \\
\text { ducts to account for } \\
\text { social cost due to energy } \\
\text { dependency. }\end{array}$ & $\begin{array}{l}\text { - Tax on inported energy } \\
\text { sources and energy } \\
\text { products to account } \\
\text { for social cost due } \\
\text { to energy dependency. }\end{array}$ & $\begin{array}{l}\text { - Jax on fmported energy } \\
\text { sources and energy } \\
\text { products to account } \\
\text { for social cost due to } \\
\text { energy dependency. }\end{array}$ & $\begin{array}{l}\text { - Iax on imported energy } \\
\text { sources and energy pro- } \\
\text { ducts to account for } \\
\text { social cost due to } \\
\text { energy dependency. }\end{array}$ & $\begin{array}{l}\text { - Tax on imported energy } \\
\text { sources and energy pro- } \\
\text { ducts to account for } \\
\text { social cost due to } \\
\text { energy dependency. }\end{array}$ \\
\hline & $\begin{array}{l}\text { High level of economic } \\
\text { activity, especially } \\
\text { energy production, could } \\
\text { give rise to adverse } \\
\text { environniental impacts. }\end{array}$ & $\begin{array}{l}\text { - Sulallest environ- } \\
\text { mental impacts be- } \\
\text { cause of low level } \\
\text { of economic activity } \\
\text { and low energy pro- } \\
\text { duction. }\end{array}$ & $\begin{array}{l}\text { - lligh level of economic } \\
\text { activity, especially } \\
\text { energy production, } \\
\text { could give rise to } \\
\text { adverse environmental } \\
\text { itmpacts. }\end{array}$ & $\begin{array}{l}\text { - Relatively low level of } \\
\text { adverse environmental } \\
\text { impacts; perhaps as } \\
\text { low as under strategy } 8 .\end{array}$ & $\begin{array}{l}\text { - High level of economic } \\
\text { activity. especially } \\
\text { energy production, } \\
\text { could give rise to ad- } \\
\text { verse environmental } \\
\text { impacts. } \\
\text { - Over-investment in build- } \\
\text { ing conservation could } \\
\text { lead to a lower level of } \\
\text { enviromintal ilapacts } \\
\text { than under strategies } \\
\text { A \& C. }\end{array}$ \\
\hline
\end{tabular}


TABLE A. (Contd)

\begin{tabular}{|c|c|c|c|c|c|}
\hline $\begin{array}{l}\text { Strategy } \\
\text { Components and } \\
\text { Criteria }\end{array}$ & $\begin{array}{c}\text { A } \\
\text { Increased } \\
\text { Reliance on } \\
\text { Marketplace } \\
\end{array}$ & $\begin{array}{c}\text { B } \\
\text { Energy Consumption } \\
\text { Tax and } \\
\text { Supply Subsidies } \\
\end{array}$ & $\begin{array}{l}\text { C } \\
\text { BEPS - No Sanctions/ } \\
\text { No Incent ives and } \\
\text { No Price Controls } \\
\end{array}$ & $\begin{array}{l}\text { D } \\
\text { BEPS - Sanctions/ } \\
\text { Incentives and } \\
\text { Price Controls } \\
\end{array}$ & $\begin{array}{l}\text { EEPS - Santions/ } \\
\text { Incentives and } \\
\text { No Price Controls } \\
\end{array}$ \\
\hline $\begin{array}{l}\text { IV. Equity } \\
\text { Income Effects }\end{array}$ & $\begin{array}{l}\text { - Inequities redressed by } \\
\text { income subs idy program } \\
\text { for poor. } \\
\text { - Total subsidies could be } \\
\text { large since all energy } \\
\text { prices increase. }\end{array}$ & $\begin{array}{l}\text { - Inequities redressed } \\
\text { by income subsidy } \\
\text { orogram for poor. } \\
\\
\text { - Total subsidies could } \\
\text { be large since all } \\
\text { energy is taxed. } \\
\text { - Tax revenues are } \\
\text { funding source for } \\
\text { subsidies } \\
\text { - Subsidies for renew- } \\
\text { able resource use } \\
\text { tend to benefit } \\
\text { middle- and high- } \\
\text { income households. }\end{array}$ & $\begin{array}{l}\text { - Inequities redressed } \\
\text { by income subsidy } \\
\text { program for poor. } \\
\text { - Total subsidies could } \\
\text { be large since all } \\
\text { energy prices increase }\end{array}$ & $\begin{array}{l}\text { - Inequities redressed } \\
\text { by income subs idy pro- } \\
\text { gram for poor. } \\
\text { - Iotal subsidies would } \\
\text { be moderate or small. }\end{array}$ & $\begin{array}{l}\text { - Inequities redressed } \\
\text { by income subsidy } \\
\text { program for poor. } \\
\text { - Total subsidies could } \\
\text { be large since all } \\
\text { energy prices increase }\end{array}$ \\
\hline $\begin{array}{l}\text { Unemployment } \\
\text { Effects }\end{array}$ & $\begin{array}{l}\text { - Price decontrol should } \\
\text { stimulate economic } \\
\text { activity, causing decrease } \\
\text { in umemployment. }\end{array}$ & $\begin{array}{l}\text { - Probably highest } \\
\text { unemployment level, } \\
\text { but depends on how } \\
\text { tax revenues are } \\
\text { spent. }\end{array}$ & $\begin{array}{l}\text { - Price decontrol should } \\
\text { stimulate economic } \\
\text { activity, causing } \\
\text { decrease in unemploy- } \\
\text { ment. } \\
\text { - Unemployment levels } \\
\text { could be more or less } \\
\text { than strategy A. }\end{array}$ & $\begin{array}{l}\text { - Unemployment levels } \\
\text { probably relatively } \\
\text { high, since price con- } \\
\text { trols depress economic } \\
\text { activity. }\end{array}$ & $\begin{array}{l}\text { - Price decontrol should } \\
\text { stimulate economic } \\
\text { activity, causing de- } \\
\text { crease in unemployment. } \\
\text { - Unemployment levels } \\
\text { could be more or less } \\
\text { than strategy A. }\end{array}$ \\
\hline
\end{tabular}


TABLE A. (Contd)

\begin{tabular}{|c|c|c|c|c|c|}
\hline $\begin{array}{l}\text { Strategy } \\
\text { Components and } \\
\text { Criteria }\end{array}$ & $\begin{array}{c}\text { A } \\
\text { Increased } \\
\text { Reliance on } \\
\text { Marketplace }\end{array}$ & $\begin{array}{c}\text { B } \\
\text { Energy Consumption } \\
\text { Tax and } \\
\text { Supply Subsidies } \\
\end{array}$ & $\begin{array}{l}\text { C } \\
\text { BEPS - No Sanctions/ } \\
\text { No Incentives and } \\
\text { No Price Controls }\end{array}$ & $\begin{array}{l}\text { D } \\
\text { BEPS - Sanctions/ } \\
\text { Incentives and } \\
\text { Price Controls } \\
\end{array}$ & $\begin{array}{l}\text { E } \\
\text { BEPS - Santions/ } \\
\text { Incentives and } \\
\text { No Price Controls }\end{array}$ \\
\hline $\begin{array}{l}\text { v. Political } \\
\text { Obstacles }\end{array}$ & $\begin{array}{l}\text { - Resistance froll groups } \\
\text { who would do better with } \\
\text { price controls. } \\
\text { Opposition from those } \\
\text { wanting higher levels of } \\
\text { energy conservation. } \\
\text { - Possible resistance to } \\
\text { PURPA from PUCs and utili- } \\
\text { ties. }\end{array}$ & $\begin{array}{l}\text { - Resistance from } \\
\text { groups opposed to } \\
\text { high consumer taxes. } \\
\text { - opposition from those } \\
\text { interested in larger } \\
\text { energy supplies. } \\
\text { - opposition from } \\
\text { groups favoring } \\
\text { greater freedom of } \\
\text { choice. }\end{array}$ & $\begin{array}{l}\text { - Resistance from groups } \\
\text { who would do better } \\
\text { with price controls. } \\
\text { - Opposition from those } \\
\text { wanting higher levels } \\
\text { of energy conservation. }\end{array}$ & $\begin{array}{l}\text { - Opposition from those } \\
\text { interested in larger } \\
\text { energy supplies. } \\
\text { opposition from groups } \\
\text { favoring greater free- } \\
\text { dom of choice. }\end{array}$ & $\begin{array}{l}\text { - Resistance from groups } \\
\text { who would do better } \\
\text { with price controls. } \\
\text { Opposition from groups } \\
\text { favoring greater free- } \\
\text { dom of choice. }\end{array}$ \\
\hline $\begin{array}{l}\text { VI. Implementation } \\
\text { Obstacles }\end{array}$ & $\begin{array}{l}\text { - Possible difficulty in. } \\
\text { adhering to tiunetable for } \\
\text { price decontrols. }\end{array}$ & $\begin{array}{l}\text { - Great difficulty in } \\
\text { selecting correct } \\
\text { amount of tax. } \\
\text { - Great difficulty in } \\
\text { maintaining correct } \\
\text { amount of tax. } \\
\text { - Usual problems with } \\
\text { implementing price } \\
\text { controls. } \\
\text { Difficulty in effi- } \\
\text { ciently allocating } \\
\text { R\&D funds. }\end{array}$ & $\begin{array}{l}\text { - Possible difficulty in } \\
\text { adhering to timetable } \\
\text { for price decontrols. } \\
\text { - Some obstacles asso- } \\
\text { ciated with application } \\
\text { of BEPS to FHA/VA hous- } \\
\text { ing and Federal bufld- } \\
\text { ing (see strategy } E \text { ). }\end{array}$ & $\begin{array}{l}\text { Usual problems with } \\
\text { implementing price } \\
\text { controls. } \\
\text { Difficulty in providing } \\
\text { implementation tools. } \\
\text { Difficulty of local } \\
\text { building officials in } \\
\text { implementing standards. } \\
\text { Building classification } \\
\text { problems. }\end{array}$ & $\begin{array}{l}\text { - Possible difficulty in } \\
\text { adhering to timetable } \\
\text { for price decontrols. } \\
\text { - Difficulty in providing } \\
\text { implementation tools. } \\
\text { - Difficulty of local } \\
\text { building officials } \\
\text { in implementing } \\
\text { standards. } \\
\text { - Building classifica- } \\
\text { tions problems. }\end{array}$ \\
\hline
\end{tabular}


TABLE A. (Contd)

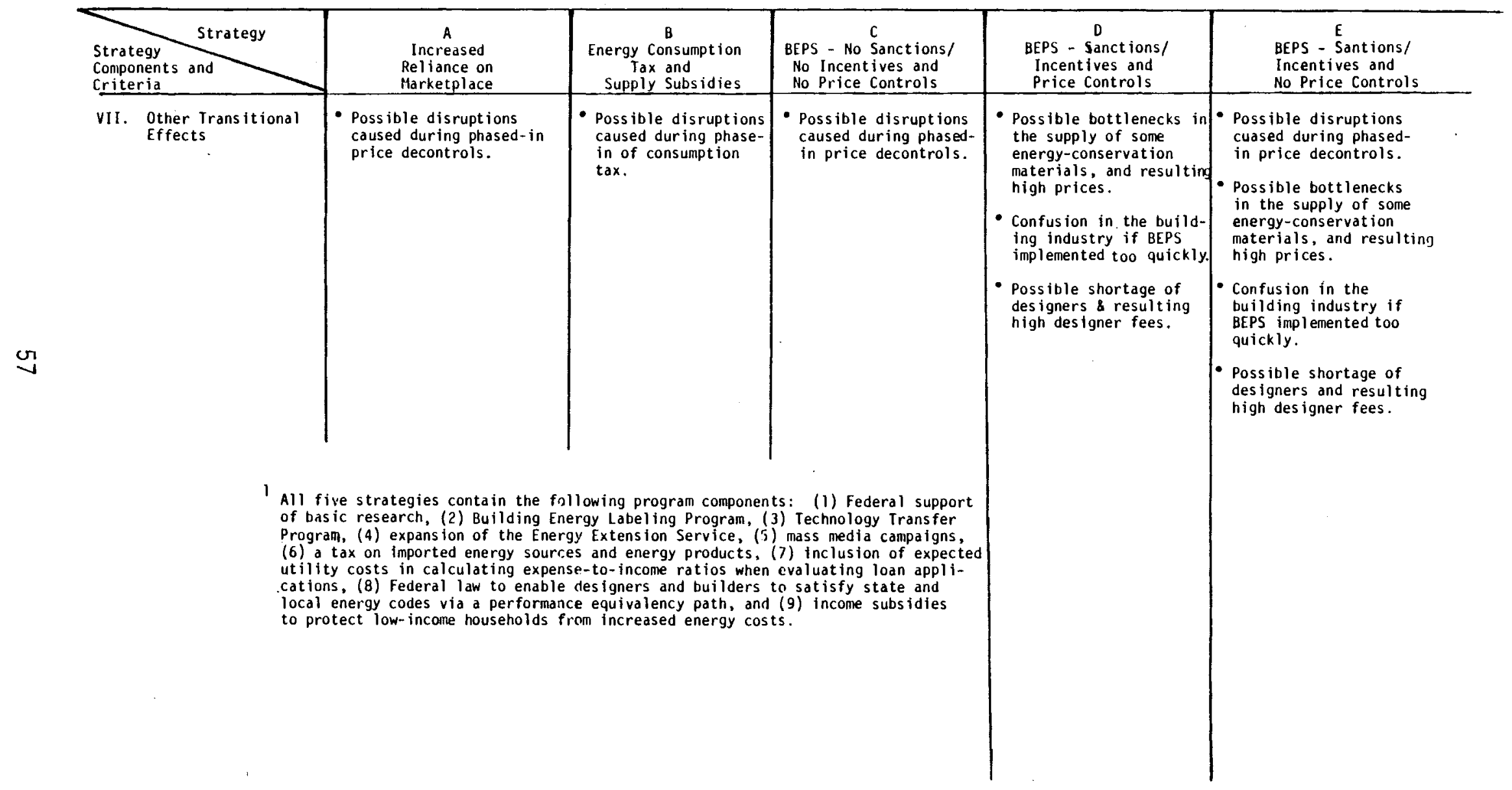


Potentially, Strategy A could achieve this optimal level, but the actual outcome depends strongly on how we 11 and to what extent consumers utilize accurate information, which is assumed to become available. Price decontrols and utilities rate reform are also expected to yield higher levels of economic activity, partly because higher energy prices will stimulate the energy industries to increase supplies. Thus, in the short-and intermediate-term, energy consumption will increase as a result of this increased economic activity. High energy prices will also stimulate the search for new, costsaving technologies and energy substitutes. To the extent that this search is fruitful, energy consumption in the longer term will be lower.

Strategy $C$ is expected to produce energy consumption levels similar to those under Strategy $A$, although minor deviations might result because of the mandatory application of BEPS to FHA/VA and Federal buildings. Strategy $E$ could yield energy consumption levels similar to Strategy $A$, but the actual outcome depends strongly on the strictness of the Standards; energy conservation could be either too little or too much.

Greater departures from the optimal conservation level are expected from Strategy B (Tax and Subsidy), simply because it seems unlikely that the tax administrators will be successful in establishing and maintaining an energy tax equal to the difference between the optimal energy price and the controlled energy price, and for all types of energy. Furthermore, energy suppliers, under this strategy, continue to face controlled prices, so they will not be encouraged to increase energy supplies. Thus, energy consumption will remain low, commensurate with the low level of economic activity. Since the search for new technologies and energy substitutes is not expected to be as intensive or extensive as the search under Strategy $A$, energy consumption in the longer term is expected to be higher.

Finally, under Strategy D (Ful1 BEPS), overall energy conservation levels are expected to depart significantly from the optimal level, because of the continuation of price controls and current utility regulatory practices. However, BEPS is very likely to achieve a much more optimal level of energy conservation in new buildings than would be the case with no BEPS and price controls. The proximity to the optimal conservation level for new buildings depends, of course, on the strictness of the applied Standards. 


\subsubsection{Economic Efficiency}

In this section we compare the five strategies according to their implications for economic efficiency. In addition to evaluating each with respect to the components of economic efficiency--distributive, production and intertemporal efficiency--we also consider the impacts of each strategy on market competition and externalities.

\section{Distributive Efficiency}

Strategy A (The Market Strategy) provides the greatest efficiency under this criterion, because it provides consumers with the greatest freedom to satisfy their wants, and because it yields an output combination having the greatest value (as perceived by consumers). Strategy $C$ (Simple BEPS) is also very efficient in this regard, although mandatory application of BEPS to FHA/ $V A$ and federal buildings causes some misallocations. Strategy $B$ (Tax and Subsidy) will be moderately efficient if the tax administrators succeed in establishing and maintaining a tax equal to the difference between optimal price and controlled price for all energy types. However, the supply-side subsidies cause distortions in the allocation of goods and services.

Strategy D (Full BEPS) is the least efficient among the five strategies. It sharply restricts freedom of choice and leaves many customers worse off, especially in view of the relatively low energy prices they face under this strategy. Finally, Strategy $E$ (Medium BEPS) is somewhat more efficient than Strategy $D$-because consumers face higher energy prices--but many consumers are still worse off because of restrictions on choice.

\section{Productive Efficiency}

Again, Strategy A (The Market Strategy) is the most efficient among the five strategies. The absence of market restrictions and the correct price signals channel resources into their highest-valued uses. The result is an output combination which consumers perceive to have the highest social value. Similarly, Strategy $C$ (Simple BEPS) yields high productive efficiency, although the mandatory application of BEPS to FHA/VA and federal buildings restricts the flow of resources to specific uses. 
Strategy B (Tax and Subsidy) is very inefficient. First of all, there are the usual distortions created by price controls. Secondly, the supplyside subsidies are seriously inadequate, partly because they fail to encourage increased production of domestic oil and natural gas. Finally, for reasons based on self-interest, the government is less likely to be as effective in allocating R\&D funds as is the market.

Strategy $E$ (Medium BEPS) is gauged to be less production efficient than either Strategy $A$ or $C$, but more efficient than Strategy $B$ and $D$. Under Strategy $E$, the mandatory Standards reduce the value of total national output by forcing resources into building conservation. However, if the Standards are not overly strict, as would be determined by consumers, this reduction could be slight.

Finally, the lowest level of production efficiency is attained under Strategy D (Ful1 BEPS). Price controls give the wrong signals to producers, and mandatory BEPS restricts the flow of resources. However, given price controls, BEPS a lmost certainly achieves a higher level of production efficiency than no-BEPS, since it tends to correct for the false price signals in the marketplace.

\section{Inter-Temporal Efficiency}

Under this criterion, The Market Strategy (Strategy A) is probably the most efficient. Deviations from efficiency will occur because market participants cannot perfectly foretell the future. Inter-temporal efficiency under Simple BEPS and Medium BEPS (Strategies $C$ and E) depends crucially on the ability of those establishing the Standards to forecast future energy prices and to apply correct discounting factors. The application of the same discount rate to all new buildings does result, however, in forcing misallocations and wealth redistributions in the future. To the extent that those establishing the Standards can better forete 11 the future and assess risk than consumers left to their own devices, and apart from issues raised by the application of discounting factors, inter-temporal efficiency could be highest under Strategy $E$ (Medium BEPS). However, failure to do as well as consumers places this strategy behind both Strategy $A$ and $C$. 
Strategy B (Tax and Subsidy) produces poor inter-temporal efficiency, since price controls prevent beneficial, inter-temporal market adjustments. Furthermore, under this strategy, it will prove very difficult to adjust the energy tax to reflect relative changes in inter-temporal scarcity.

Strategy D (Fu11 BEPS) provides the lowest degree of inter-temporal efficiency because of the distortions created by price controls. However, BEPS provides a much better inter-temporal allocation of conservation resources than would a price-controlled market without BEPS.

The speed with which potential energy savings are realized is an important issue and one that relates to inter-temporal efficiency. The speed under Strategy A (The Market Strategy) depends closely on the public's response to higher energy prices and on the rate at which relevant information is disseminated and utilized. The speed under Strategy $B$ (Tax and Subsidy) will be sim$i l a r$ to that under Strategy $A$ if the prices consumers face are also similar. The Strategy C (Simple BEPS) speed could be faster than either of the above, partly because some states may adopt mandatory BEPS. The speed under Strategy $D$ (Ful1 BEPS) is probably the slowest because of the effect of energy price controls. Finally, the speed under Strategy $E$ (Medium BEPS) will depend on when BEPS is implemented and on the ease of implementation. The speed could be the fastest under this strategy, but with delay or difficulties it could also be among the slowest.

\section{Impact on Market Competition}

The highest level of market competition is expected to be achieved under Strategy A (The Market Strategy), followed closely by Strategy C (Simple BEPS). Under Strategy B (Tax and Subsidy) the level of competition among suppliers of energy is expected to be lower because low energy prices will keep some potential suppliers from producing, and the regulatory burden will discourage others. Strategy D (Full BEPS) also suffers from these adverse impacts on competition. In addition, the regulations and restrictions associated with BEPS may keep many potential suppliers of building materials and buildings out of the market. In some cases, suppliers of building materials may be able to exercise a socially unacceptable level of market power. For these reasons, Strategy $D$ is expected to have the greatest adverse impact on market 
competition. Strategy $E$ (Medium BEPS) suffers from the same competitive impacts as Strategy D (Full BEPS), except for the adverse impacts within the energy supply industries.

\section{Externalities}

The tax on imported energy sources and energy products will cause the market to accurately reflect the social cost of increased national dependency on imported energy.

External (to the market) impacts on the environment are expected to vary among the five strategies. The high level of economic activity, especially that related to energy production, could give rise to adverse environmental impacts under Strategy A (The Market Strategy) and C (Simple BEPS). Any over-investment in building conservation under Strategy $E$ (Medium BEPS) would probably result in fewer adverse environmental impacts than under either Strategy A or C. Strategy B (Tax and Subsidy) is expected to cause the least environmental damage because of low energy production and low levels of economic activity. For similar reasons, the Strategy $D$ (Full BEPS) environmental impacts would also be very low.

\section{2 .3 Equity}

In this section we compare the five strategies according to the ir equity impacts. In particular, they will be examined for their effects on income distribution and on unemployment.

\section{Income Effects}

A supplemental income subsidy program is assumed to exist under all five strategies. The purpose of the program is to shield low-income groups from the effects of higher prices. Thus, the income effects of all strategies will be approximately the same, although the amount of subsidies required to achieve this result will vary from strategy to strategy. Total subsidies could be relatively large under Strategies A (The Market Strategy), C (Simple BEPS), and E (Medium BEPS), since price decontrol and utility rate reform are expected to result in significantly higher energy prices. Total subsidies would be relatively small under Strategy D (Full BEPS). since prices remain controlled and utility rates are not reformed. Under Strategy B (Tax and 
Subsidy), consumers are not shielded from the effects of high energy prices, because of the tax. Subsidies, in addition to those for low-income groups, are slated under this strategy for stimulating renewable resource use. It is noted that such subsidies tend to be regressive, as they benefit middle- and high-income households at the expense of others. While total subsidies could be greatest under this strategy, they could be funded from the proceeds of the energy tax.

\section{Unemp loyment Impacts}

Because price decontrols are expected to increase the level of economic activity, they should beneficially impact the unemployed. Strategies $A, C$, and $E$ call for price decontrols. However, because these strategies result in different output mixes, their impact on unemployment is likely to differ. The highest unemployment levels are probably achieved under Strategy B (Tax and Subsidy), but the outcome depends on how the energy tax revenues are spent. Strategy D (Full BEPS) which requires price controls, would probably give rise to relatively high unemployment.

\subsubsection{Political Obstacles}

Resistance to Strategy A (The Market Strategy) is expected from groups who benefit from price controls and from those who want society to achieve a higher (possibly above-optimal) level of energy conservation. In addition, public utility commissions and utilities may resist implementing some or al1 provisions of PURPA. Strategy $C$ (Simple BEPS) and, possibly to a lesser extent, Strategy $E$ (Medium BEPS) could encounter similar resistance.

Strategy B (Tax and Subsidy) could be opposed by groups against higher consumer taxes, by those in favor of stimulating domestic supplies of $0 i 1$ and natural gas, and by groups who place a premium on economic freedom of choice. Finally, Strategy $D$ (Full BEPS) would be opposed by the latter two of these groups.

\subsubsection{Implementation Obstacles}

The main obstacle to implementing Strategy A (The Market Strategy) lies in the possible difficulty of adhering to the timetable for price decontrols. 
We note that Congress is already threatening to delay implementation of the first step in the decontrol of natural gas prices. Strategies $C$ and $E$ also suffer from this obstacle.

In addition there are potential obstacles to implementing BEPS. These include: difficulty in providing the implementation tools in time (August 1981), difficulty of local building officials in implementing the Standards, and problems with developing a satisfactory classification of building types. Strategies $C, D$, and $E$ would be affected by these potential obstacles.

Strategy $B$ requires establishing and maintaining a tax equal to the difference between the optimal energy price and the controlled price for all energy types. This could prove extremely difficult to achieve in practice. This strategy also suffers from the usual problems of implementing and administering price controls and from the difficulty in efficiently allocating R\&D funds.

\subsubsection{Other Transitional Effects}

Some other adverse transitional impacts are identified in this section. Strategies $A, C$, and $E$ could cause some market disruptions during the period in which prices are gradually decontrolled. Strategy $B$ could cause similar disruptions during phase-in of the energy consumption tax. Finally, three potentially serious transitional impacts are identified for Strategies $D$ and $E$ (Full and Medium BEPS): (1) possible bottlenecks in the supply of some energy conservation materials could occur, with temporarily high prices for these materials; (2) there could be considerable confusion within the building industry if BEPS is implemented too quickly; and (3) there could be a shortage of design professionals, resulting in temporarily high design fees.

\subsection{SUMMARY}

This section presents a comparative analysis of the five alternative strategies for promoting energy conservation and the use of renewable resources in new buildings. The five strategies are: Increased Reliance on the Marketplace (Strategy A, or Market Strategy), Energy Consumption Tax with Supply Subsidies (Strategy B, or Tax and Subsidy), BEPS - No Sanctions/No 
Incentives and No Price Controls (Strategy $C$, or Simple BEPS), BEPS Sanctions/Incentives and Price Controls (Strategy O, or Full BEPS), and BEPS - Sanctions/Incentives and No Price Controls (Strategy E, or Medium BEPS). The criteria by which the strategies are evaluated are: energy conservation, economic efficiency (distributive, production and inter-temporal) including impacts on market competition and impacts of externalities, equity, including income distribution and unemployment; political obstacles; implementation obstacles; and other transitional effects. Some summary comments on the advantages and disadvantages of each strategy are presented below:

Strategy A: Increased Reliance on the Marketplace

Advantages:

- Once higher energy prices have been adjusted to, energy conservation is probably close to optimal level, especially if consumers fully use available information.

- Most economically efficient among the five alternatives, although it is possible that Strategies $E$ (Medium BEPS) and, to a lesser extent, C (Simple BEPS) could achieve greater intertemporal efficiency.

- Moderate to fast achievement of energy savings during adjustment period.

- Achieves the highest level of market competition among the five alternatives.

- Achieves relatively low level of unemployment.

- Price decontrols cause high level of economic activity, especially among energy suppliers.

- Encourages high level of energy-saving technologies.

Disadvantages:

- High level of economic activity causes higher energy consumption. 
- High level of economic activity may cause adverse environmental impacts, especially among energy suppliers.

- Total income subsidies to low-income groups could be large, because all energy prices are decontrolled; mitigated to some extent by high employment and income levels.

Strategy B: Energy Consumption Tax with Supply Subsidies

Advantages:

- High taxes reduce total energy consumption.

- Moderately efficient with respect to distributive efficiency, but supply-side subsidies distort resource allocation.

- Moderate to fast achievement of energy savings during adjustment period.

- Smallest environmental impacts because of low level of economic activity and low level of energy production.

- Tax revenues provide funding source for subsidies.

Disadvantages:

- Very poor production and inter-temporal efficiency.

- Low level of economic activity and high level of unemployment.

- Fewer energy-saving technologies are produced than under Strategies A (Market Strategy), C, and E (Simple and Medium BEPS).

- Supply-side subsidies seriously inadequate; no subsidies to encourage more domestic oil or natural gas.

- For reasons based on self-interest, government allocation of $R \& D$ funds probably less efficient than market allocation of R\&D funds.

- Reduced level of market competition among energy suppliers. 
- Total income subsidies to low-income groups could be large, since a 11 energy is taxed.

- Very serious implementation obstacles (see Table A).

Strategy C: BEPS - No Sanctions/No Incentives; No Price Controls

Advantages:

- Once higher energy prices have been adjusted to, energy conservation is probably close to optimal level, especially if consumers fully use available information.

- Slightly less economically efficient than Strategy A (Market Strategy), but more efficient than other strategies.

- Moderate to fast achievement of energy savings during adjustment period.

- Achieves very high level of market competition.

- Achieves high level of economic activity, especially among energy suppliers.

- Achieves relatively low level of unemployment.

Disadvantages:

- High level of economic activity causes higher energy consumption.

- High level of economic activity may cause adverse environmental impacts, especially from energy suppliers.

- Total income subsidies to low-income groups could be large, because all energy prices are decontrolled; mitigated to some extent by high employment and income levels.

- Contains some implementation obstacles associated with the application of BEPS to FHA/VA and federal buildings (see Table A). 


\section{Strategy D: BEPS - Sanctions/Incentives; Price Controls}

\section{Advantages:}

- Low level of economic activity results in low energy consumption.

- Low level of economic activity results in low level of adverse environmental impacts.

- Because energy prices are controlled, total subsidies to lowincome groups would be low.

Disadvantages:

- Relatively few energy-saving technologies are developed, as compared with the other strategies.

- Has the lowest economic efficiency among the five alternatives.

- Slow to moderate achievement of energy savings because of price controls.

- Has greatest adverse impact on market competition among the five alternatives.

- Low level of economic activity causes high unemployment levels.

- Low level of economic activity results in low output value.

- Domestic production of $0 i 1$ and natural gas remains at low levels.

- Contains some obstacles to implementing BEPS (see Table A).

Strategy E: BEPS - Sanctions/Incentives; No Price Controls

Advantages:

- High number of energy-saving technologies are developed.

- Very efficient in terms of productive efficiency, but not as efficient as either Strategy $A$ (Market Strategy) or Strategy $C$ (Simple BEPS). 
- Inter-temporal efficiency could be very good, or very bad, depending on ability to forecast future energy prices and apply correct discount rates.

- Moderate to fast achievement of energy savings during adjustment period.

- Relatively high level of economic activity results in relatively low level of unemployment.

Disadvantages:

- High level of economic activity causes higher energy consumption.

- Not economically efficient, in terms of distributive efficiency.

- Some adverse impacts on market competition.

- High level of economic activity may cause adverse environmental impacts, especially from energy suppliers.

- Total income subsidies to low-income groups could be large, because all energy prices are decontrolled; mitigated to some extent by high employment and income levels.

- Contains some obstacles to implementing BEPS (see Table A). 



\section{CONCLUSIONS}

This paper began by identifying and discussing barriers to increased energy conservation and greater use of renewable resources in new buildings. Then individual policy instruments for dealing with these barriers were categorized and explained. Five alternative strategies, consisting of different policy instruments, were then evaluated according to criteria established earlier. In concluding this analysis, some additional observations are offered and a comprehensive strategy is recommended.

\subsection{ADDITIONAL OBSERVATIONS}

In summarizing the analysis in the previous sections, several observations stand out.

First, the effectiveness of the price mechanism tends to be underrated. As the prices of oil, natural gas, and electricity are allowed to rise through deregulation, decontrol, and utility rate reform, both consumption and supplies are affected. Wasteful use of energy is discouraged and, at the same time, domestic supplies of these conventional energy forms are increased. Furthermore, the use of alternative energy resources becomes more economically attractive and the development of new technologies and energy substitutes are stimulated. Moreover, the impacts prevail over the entire economy and are not limited to a specific sector.

Nevertheless, while these benefits are often acknowledged, such marketbased solutions are frequently ignored in public policy formulation because (a) price increases resulting from decontrol/deregulation tend to exacerbate the perceived short-term inflation problem, (b) rising energy prices tend to impose an inequitable financial burden on low-income families, (c) the price mechanism may yield the desired effects only after a substantial time 1 ag, and (d) in some instances, a rise in energy prices may occur at the same time as an increase in aggregate consumption of energy, apparently contradicting the principle that rising energy prices reduce energy use. With respect to these points, it should be noted that suppressing prices imposes other costs on the economy in the form of shortages, increased waiting time, 
and chronic dislocations in both demand and supply sectors. It is also important to realize that price decontrol/deregulation improves resource utilization and potentially increases the total value of the economy's output. In this sense, it is inherently counter-inflationary. (For more discussion on the subject of inflationary impact see Appendix A.) Also, we have observed that direct income transfer programs can be very effective in dealing with the equity problems arising from energy price increases. Furthermore, all of the strategies require time to achieve their results, and it is not at all clear that other approaches are quicker than a policy of price deregulation/ decontrol. The alternative approaches, because of government interference, also introduce distortions into the economic decision-making process. Note, finally, that the observed contradiction to the downward-sloping demand schedule is more apparent than real, because rising energy prices have been accompanied by growing population, higher incomes, and large increases in other prices. It is concluded from these considerations that the current policies of price decontrol/deregulation and utility rate reform should be continued and vigorously implemented.

Second, as mandated by Congress in ECPA of 1976, BEPS is the specific policy instrument for achieving the objective of promoting energy conservation and use of renewable resources in new buildings. To this end, substantial research and analys is have been completed to support the promulgation and implementation of BEPS. This research has been most beneficial in enhancing our knowledge of energy consumption and conservation in the built environment. On the other hand, major difficulties have been encountered, some of which remain unresolved. Two such unresolved issues are noted below:

- To accomodate regional disparities, forecasts of region-specific marginal costs of each major type of energy are required for a long period of time (30-40 years). There is, of course, much uncertainty in such projections.

- The weighting factors, which relate to the rate of substitution between electricity, natural gas, or $0 i 1$ in calculating Design Energy Budgets and Design Energy Consumption, are very controversial and are likely to remain so. 
Moreover, a decision must be made whether to implement BEPS with sanctions and/or with incentives. There are many reasons to believe that direct financial or administrative sanctions--such as denial of federal loans, insurance, or guarantees to builders and home buyers for new building construction-would not be appropriate at this time (DOE 1980a); indeed, such sanctions are likely to be counterproductive:

- The sanctions require Congressional approval. In the current political climate, the likelihood of this approval seems low.

- As currently proposed by DOE, BEPS involves new concepts, new computational tools, and most likely new institutional arrangements for its implementation. Since state and local jurisdictions may lack expertise, funds, and staff, federal financial incentives and technical assistance would seem justified. Moreover, even with federal assistance, a period of gradual adjustment for instituting the necessary legal and institutional framework would be necessary (Graves and Fletcher 1980). Therefore, it does not seem equitable to impose sanctions before an appropriate adjustment period.

- At present, inflation and high interest rates have caused a depression in the housing industry. To apply federal financial sanctions would further aggravate this situation.

Third, the information, education, and demonstration programs play an important role in each strategy for promoting energy conservation and use of renewable resources. These programs can be instrumental in explaining the current policies of deregulation, decontrol and utility rate reform. They can be used to elucidate life-cycle costing, to educate various audiences on the BEPS program, to transmit information on energy conservation practices and nove 1 renewable resource technologies, and to inform consumers about the availability of various incentive programs. In other words, the information, education, and demonstrate programs should be an integral part of any strategy in furtherance of optimal energy conservation.

Fourth, in light of the social cost imposed on this nation by increased dependence on imported energy sources, it appears appropriate to apply a tax 
on a 11 imported energy and energy products. Furthermore, if optimal energy conservation is not realized quickly enough under the price deregulation/ decontrol program, energy consumption could be taxed further and/or subsidies offered to encourage greater conservation.

Fifth, federal support of basic research is strongly encouraged. Such research is likely to result in energy applications which will prove significant in solving our long-range energy problems.

Finally, our analysis of the five strategies in Section 5 indicated that much of the information and analysis developed in the course of the BEPS research significantly enhances the effectiveness of a 11 five strategies. The analysis also suggests that implementation of BEPS on a largely voluntary basis is only slightly less efficient, and under certain circumstances, possibly more efficient than relying totally on the marketplace. These conclusions are consistent with a comprehensive strategy that calls for the cautious implementation of BEPS. Furthermore, existing law requires implementation of BEPS, and this argues for including some form of BEPS within an overall strategy. $(a)(b)$

(a) It is important to evaluate BEPS in its historical context. Enacted prior to legislation and/or actions decontrolling the prices of natural gas (1978) and $0 i 1$ (1979), it offered a major opportunity to conserve on energy in an environment where artificially low prices encouraged excessive energy use. In this respect, BEPS, energy price decontrols and a tax on energy consumption can be viewed as alternative ways of achieving a more optimal level of energy conservation. When BEPS was enacted, the prospects for decontrolling energy prices were far from certain, and the political unpopularity of imposing a heavy tax on energy consumption was, and remains, great. Add to this the low public response to voluntary conservation measures, and BEPS provides a reasonable approach for effecting a timely reduction in the energy that would be used in new buildings.

It is based upon such perspective that the Regulatory Analys is Review Group recommended that (1) DOE "consult with Congress as to the feasibility of postponing the date of promulgation of final BEPS or the date of effectiveness of the final Standards," and (2) that DOE "undertake a comprehensive reassessment of the present need for and desirability of BEPS" (Council on Wage and Price Stability 1980).

(b) In early June, 1980, DOE announced that is suance of the final regulations for the BEPS would be delayed until August, 1981. 


\subsection{ELEMENTS OF A PROPOSED STRATEGY}

It follows from the above discussion that several elements can be proposed for inclusion in an overall strategy for promoting an optimal level of energy conservation.

Two-Stage Imp lementation of BEPS

- Implement BEPS with incentives and no sanctions for an initial period of two to four years.

- At the end of the initial implementation period, Congress may want to evaluate the results as well as the conditions prevailing at that time to decide whether to fully implement BEPS with sanctions and incentives, to continue the BEPS-incentives/no sanctions approach, or to abandon BEPS entirely and adopt some alternative voluntary approach.

\section{Decontrol/Deregulation/Utility Rate Reform}

- Crude $0 i 1$ Price Decontrol - Maintain the current timetable of phased decontrol and refrain from re-imposition of controls.

- Natural Gas Price Deregulation - Consider a new legislative proposal to increase the speed of deregulation; residential and commercial customers should be brought within the scope of decontrolled prices more rapidly.

- Wholesale Electric Rate Regulation - In conducting wholesale electric rate-making proceedings, the FERC should adhere to marginal cost pricing principles.

- Retail Utility Rate Reform - Vigorously implement PURPA.

$\underline{T a x}$ and Subsidy

- Tax - Apply a tax to imported energy and energy products to reflect the social cost imposed by increased national energy dependence.

- Subsidy - Grant income subsidies to low-income groups to shield them from the financially burdensome effects of higher energy prices. 
The subsidies should take the form of income supplements, rather than direct energy subsidies, so that energy conservation among the poor will be encouraged.

Information, Education, and Demonstration Programs

- Building Energy Labeling Program - Require that estimates of the Design Space-Conditioning Costs (DSCC) of all new buildings be available to all potential buyers or renters prior to the time of sale or occupancy.

- Technology Transfer Program - Establish a program to facilitate technology absorbtion by the building industry. The program could include seminars and workshops, a pool of experts available to the building industry, and, possibly a model building demonstration program.

- Energy Extension Service (EES) - Accelerate the expansion of the EES from the ten-state pilot program to all fifty states.

- Mass Media Campaign - Utilize the audio-visual and print media to inform the public of new energy developments and programs and other energy-related information.

\section{Research}

- Federal Support of Basic Research - Increase the level of federal support for basic research, particularly in the energy area. 
APPENDIX A

NOTE ON THE RELEVANCY OF EXECUTIVE ORDER 12185 TO BEPS 
APPENDIX A

NOTE ON THE RELEVANCY OF EXECUTIVE ORDER 12185 TO BEPS

Executive Order 12185, signed December 17, 1979, was issued "in order to encourage additional conservation of petroleum and natural gas by recipients of federal financial assistance...."

Paragraphs of this Order that may be relevant to BEPS are:

1-102. Each Federal agency which extends financial assistance shall review those programs of financial assistance and identify those which are most likely to offer opportunities for significant conservation of petroleum and natural gas.

1-106. No one shall be awarded any financial assistance unless that award complies with the provisions of the conservation rules adopted by the agency pursuant to this Order.

1-107. To the extent permitted by 1 aw and where not inconsistent with the financial assistance program, final rules may provide for the reduction or suspension of financial assistance under any award. Such reduction or suspension shall not be ordered until there has been an opportunity for a hearing on the record, and shall last for such time as the recipient fails to comply with the terms of the conservation rule.

1-108. No conservation rule shall be adopted which is inconsistent with the statutory provisions establishing the financial assistance program.

The relevancy of Paragraph 1-102 hinges upon the capacity for BEPS to achieve "significant conservation of petroleum and natural gas." As currently proposed, the Building Energy Performance Standards use weighting factors to determine Energy Budget Levels, and ultimately Design Energy Budgets for specific buildings. The use of these weighting factors results in Design Energy Budgets which are significantly more stringent (by a factor of about 3 ) for an all-electric building than for an identical building that would utilize only natural gas or oil. 
During public hearings on BEPS, electric utilities and others have argued that the weighting factors would strongly discourage the use of electricity and encourage the use of natural gas and $0 i 1$. While the research conducted for BEPS suggests that the net energy impact of BEPS would result in a net reduction in the use of natural gas and oil, the high frequency of comments directed against the weighting factors would at least argue that the conclusion of the contract research should not be taken for granted. If Executive Order 12185 is to apply to BEPS, it may have to be demonstrated under legal challenge that BEPS would indeed "offer opportunities for significant conservation of petroleum and natural gas."

Section 305 of the Energy Conservation Standards for New Buildings Act of 1976 (Pub. L. 94-385, 42 U.S.C. et seq.) states that "no Federal financial assistance shall be made available for the construction of any new commercial or residential building in any area of any state" unless certain actions are taken by the state and local governments to avoid imposition of the sanction. However, each House of Congress must approve the sanction before the sanction can be applied.

Federal financial assistance is defined in Section 303(3) of the Act as:

1. Any form of loan, grant, guarantee, insurance payment, rebate subsidy, or any other form of direct or indirect Federal assistance (other than general or special revenue sharing or formula grants made to states) approved by any Federal officer or agency; or

2. Any loan made or purchased by any bank, savings and loan association, or similar institution subject to regulation by the Board of Governors of the Federal Reserve System, the Federal Deposit Insurance Corporation, the Comptroller of Currency, the Federal Home Loan Bank Board, the Federal Savings and Loan Insurance Corporation or the National Credit Union Association.

It is clear from the above that "federal financial assistance" is defined very broadly and excludes only "general or special revenue sharing or formula grants made to states." 
Since, under existing law, federal financial assistance, as defined above, shall not be withheld without the concurrence of both Houses of Congress, Paragraph 1-107 of the Executive Order would seem to apply: "To the extent permitted by law,... final rules may provide for the reduction or suspension of financial assistance under any award" (emphasis added).

Under this interpretation, Executive Order 12185 could embrace BEPS only to the extent that "any award" includes "general or special revenue sharing or formula grants made to states," in which case Paragraphs 1-106 and 1-108 would apply.

Further interpretation of Executive Order 12185 is we 11 beyond the expertise of the authors, neither of whom has a legal background. 

APPENDIX B

A NOTE ON INFLATIONARY IMPACTS 
APPENDIX B

\section{A NOTE ON INFLATIONARY IMPACTS}

In these economically turbulent times, the inflationary impacts of a policy must be of central concern. There are, however, certain difficulties in gauging a policy's inflationary impact. First of all, there is considerable controversy regarding the causes of inflation, a discussion of which is beyond the scope of this note. Secondly, there is also much confusion surrounding inflation issues. This is illustrated by the following examples.

"Excess demand" is often attributed as a cause of inflation, but "excess demand" can be at least two different things. One type of "excess demand" occurs when too much money is chasing too few goods (excessive growth of the money supply). In such circumstances, the prices of nearly all commodities will be bid up. This type of inflation is cured by reducing money supply growth.

On the other hand, "excess demand" can result if a relatively large share of society's resources is being used to produce capital goods and a relatively small share to produce consumer goods. The high incomes generated by this burgeoning economic activity may result in a "shortage" of consumer goods and cause prices to rise. However, this is a temporary phenomenon and the proper balance between consumer and capital goods will eventually be restored by normal market forces.

The fact that both types of "excess demand" are given the same label can easily lead to erroneous policy prescriptions. For example, a tax increase-of ten a prescription for excess demand-would be harmful in the second example. It would probably be ineffective or harmful in the first example if the tax increase is not used to reduce the money supply.

The causes of inflation are often confused with the effects of inflation. For example, one view holds that wage increases are predominantly the result of inflation, while another view sees such increases as basically a cause. 
Finally, inflation, which is defined as an increase in the general price level, is often confused with increases in relative prices, which are commodity specific. To illustrate, excessive growth of the money supply will generally result in an increase in the general price level--it's inflationary. But a shift in the supply or demand for a commodity is not by itse if inflationary. As a result of the shift, the price of the commodity may increase, but the prices of other commodities must decrease. The effects of such shifts are often misleading because, while there may be a dramatic rise or fall in the price of one or a few commodities, the counterbalancing price adjustments will usually be highly diffused among many other commodities. For this reason it is important, when evaluating public policies, not to confuse a short-run increase in the relative price(s) of one or several commodities-which may indeed cause a price index to rise temporarily--with the long-run effects of the policy.

A case in point is price decontrol. A commodity whose price is decontrolled may rise sharply in the short-run--a relative price increase--but decontrol will lead to a more efficient utilization of resources. After the adjustments have occurred, the value of total output has increased for a given value of resource inputs, and this is, by definition, counter-inflationary. Thus, such a policy increases relative prices in the short-run but is counter-inflationary in the longer run.

Given the intricacies suggested above in gauging the causes of inflation, not to mention the confusions surrounding inflation, attempts to measure the impacts on inflation of a wide-ranging policy should be viewed with considerable caution, if not skepticism. For these reasons, inflationary impacts in this report are considered only to the extent that they result from differences in the efficient use of resources, for in this case we are on firm ground. 
REFERENCES

Baumo 1, W. J., et. al. 1979. Economics, Environmental Policy, and the Quality of Life.

Berg, C. A. 1979. Energy Conservation in Industry: The Present Approach, The Future Opportunities, prepared for Council on Environmental Quality, Washington, D.C.

California Public Utilities Commission. 1980. Energy Efficiency and the Utilities: New Direction, a symposium held at Stanford University, Apri1 18-19, 1980, published July 1980.

Council on Wage and Price Stability. 1980. Report of the Regulatory Analysis Review Group on the Department of Energy's Proposed New Buildings Energy Performance Standards (BEPS), Draft (Apri1 16, 1980), Washington, D.C.

Electric Power Research Institute (EPRI). 1979. Overview and Strategy: 1980-1984 Research and Development Program Plan. PS 1141 SR, Pa10 ATto, California.

Graves, T. P. and J. Fletcher. 1980. Final Report - Building Energy Performance Standards. H-4328, U.S. Conference of Mayors, Washington, D.C.

National Science Board. 1979. Science Indicators, 1978. National Science Foundation, Washington, D.C.

Office of Technology Assessment. 1979. Residential Energy Conservation. Washington, D.C.

San Jose Mercury. 1980. February 6, 1980.

U.S. Department of Energy (DOE). 1979a. U.S. Conservation Strategy, Draft, Office of Conservation and Solar Energy, November 2, 1979, Washington, D.C.

U.S. Department of Energy (DOE). 1979b. Economic Analys is of Energy Performance Standards for New Buildings. Office of Conservation and Solar Energy, Washington, D.C.

U.S. Department of Energy (DOE). 1979c. Draft Regulatory Analysis: Energy Performance Standards for New Buildings. Office of Conservation and Solar Energy, Washington, D.C.

U.S. Department of Energy (DOE). 1979d. Draft Environmental Impact Statement: Energy Performance Standards for New Buildings. Office of Conservation and Solar Energy, Washington, D.C.

U.S. Department of Energy (DOE). 1980a. Draft Environmental Impact Statement: Implementation of Energy Performance Standards for New Buildings.

Office of Conservation and Solar Energy, January 1980, Washington, D.C. 



\section{DISTRIBUTION}

No. of

Copies

\section{OFFSITE}

A. A. Churm

DOE Patent Division

9800 S. Cass Avenue

Argonne, IL 60439

27 DOE Technical Information Center

M. Savitz

U.S. Department of Energy Washington, DC 20545

J. Cable

U.S. Department of Energy Washington, DC 20545

10 P. Back

U.S. Department of Energy Washington, DC 20545

S. Dunne

U.S. Department of Energy Washington, DC 20545

A. Twitche 11

U.S. Department of Energy Washington, DC 20545
No. of

Copies

5 R. Menge

U.S. Department of Energy

Washington, DC 20545

\section{ONSITE}

DOE Rich land Operations

H. E. Ransom

57 Pacific Northwest Laboratory

J. W. Currie

D. E. Deonigi

J. M. Fang (10)

T. J. Foley

L. A. Nieves

J. Tawil (5).

Economics Library (20)

Technical Information (5)

Publishing Coordination KE(2) 
